\title{
Traditional Biodiversity Conservation Strategy As A Complement to the Existing Scientific Biodiversity Conservation Models in Ghana
}

\author{
Dickson Adom ${ }^{1}$ \\ ${ }^{1}$ Kwame Nkrumah University of Science and Technology, Ghana \\ Correspondence: Dickson Adom, Kwame Nkrumah University of Science and Technology, Ghana. E-mail: \\ adomdick@yahoo.com
}

Received: May 1, 2018

Accepted: June 5, 2018

Online Published: June 18, 2018

doi: 10.5539/enrr.v8n3p1

URL: https://doi.org/10.5539/enrr.v8n3p1

\begin{abstract}
Biodiversity management in Ghana has been largely driven by scientific conservation models. The time-tested and useful traditional conservation ethos in the Ghanaian cultural and artistic elements such as festivals, proverbs, cosmological belief systems and taboos are often watered down by conservationists in biodiversity conservation schemes. This is due to conservationists' lack of clear-cut guidelines on how to effectively utilize the traditional knowledge systems in complementing the scientific conservation models they are well versed. The developed traditional biodiversity strategy was based on the findings from a robust phenomenological study conducted among purposively and randomly sampled key stakeholders in biodiversity management in the Ashanti Region of Ghana. The document aims at offering comprehensive information and guidelines to conservationists on effective ways of implementing traditional knowledge systems in biodiversity conservation issues in Ghana. It ultimately aims at filling the dearth in traditional knowledge systems that have been an age-long problem for the conservation ministries and agencies in Ghana. The informative directions in the developed traditional biodiversity strategy would offer another lens to addressing conservation issues in Ghana while acting as a viable complement to the scientific models. This would ultimately maximize and enrich the conservation strategies for managing Ghana's biodiversity.
\end{abstract}

Keywords: biodiversity conservation, traditional knowledge systems, culture, traditional conservation strategy

\section{Introduction}

Biodiversity conservation has been a major priority of governments globally because of the alarming rate of biodiversity depletion. This menace in biodiversity has raised serious eyebrows among conservation agencies and global networks responsible for the protection of the biological diversity. The United Nations have earmarked a decade from 2011-2020 as the world's decade on biodiversity protection (Bettson, 2010). Also, member countries of the United Nations recently signed and ratified the Convention on Biological Diversity Aichi Targets to help bolster the strategies taken by member countries in conserving the rich bio-resources in nature. These attempts are crucial and indispensable due to the pivotal and non-exchangeable roles that biodiversity plays in the lives of humans. There is therefore the call for multi-faceted strategies to help in arresting the biodiversity depletion canker. There is the search for these pluralistic strategies from various streams of knowledge, unlike the previously often biased truncated approach to scientific conservation strategies. Thus, there is a realization of the worth of conservation ethos in the traditional ecological knowledge systems which are usually in the preserve of local communities of countries. As a result, many countries are now seriously researching into how the traditional wisdom regarding the use and conservation of resources and how they can be used to complement the often emphasized scientific conservation practices which are equally relevant. Many countries have set examples worth emulating in the utilization of traditional wisdom latent in the cultural and artistic elements of the people, such as their cosmological beliefs, taboos, proverbs, myths, folklore and so forth. Countries that have taken these giant and relevant steps in integrating traditional knowledge into their modern scientific models of conservation have attained a great degree of successes. They include Brazil, China, India, Japan, Kenya, Angola and Tanzania (For extensive information read Adom, 2016b). These countries have used traditional conservation practices' education and awareness campaigns, documentation, active participation of the stakeholders of the traditional wisdom, and many other strategies. This has aided in the recognition, appreciation, and promotion of traditional conservation practices evident in the cultural and artistic 
elements of their people. This is in fulfillment of the Aichi target 18 that instructed signatory nations that 'By 2020, the traditional knowledge, innovations and practices of Indigenous and local communities relevant for the conservation and sustainable use of biodiversity, and their customary use of biological resources, are respected, subject to national legislation and relevant international obligations, and fully integrated and reflected in the implementation of the convention with the full and effective participation of Indigenous and local communities, at all relevant levels' (CBD, 2010, Article 18).

The precepts set by the already cited countries and their allied benefits show clearly the need for countries with rich sources of traditional knowledge such as Ghana to consider developing a robust traditional conservation strategy as a viable complement to the scientific conservation practices that seem very populous in the management of her biological diversities.

\subsection{Defining the Problem that necessitated the Traditional Biodiversity Strategy}

Ghana is a country with rich traditions and a robust cultural heritage. Her cultural buoyancy is remarkable and has been enviable on the African continent and among her global contenders. The genius forebears in Ghana cleverly established, instituted, initiated and observed several forms of cultural and artistic elements that were latent with rich traditional wisdom and ethos that ensured the development of self and the Ghanaian community as a whole. Interestingly, these creatively fashioned cultural and artistic elements that form part of the life experiences of the Ghanaian people hold great benefits today even in the face of astronomical development in the field of science and technology. The unique roles that they play in the society are tremendously relevant in maintaining peaceful relations between the Ghanaian people and their environment. These rich cultural and artistic elements include the cosmological belief systems of the Ghanaian people, the observation of taboos, the celebration of festivals, the deep pondering and use of proverbs for education and many others. These cultural and artistic elements have a great worth of traditional conservation knowledge for the management of biodiversity. In fact, they were and are still potent strategies used for the conservation of biodiversity. Many of the tracts of lands in Ghana that have been maintained in their pristine forms have resulted from the promulgation of the resilient cultural and artistic elements by various communities in this country.

It is quite unfortunate that the policies and strategies for biodiversity in Ghana have not exemplified these cultural and artistic elements to make their application in the management of biodiversity less cumbersome. Ghana has been carried away more in the scientific conservation practices, relegating and/or minimizing the great potentials in the traditional conservation knowledge in the conservation of her biodiversity resources. The recently released National Biodiversity Strategy has highlighted the need for a documentation of all traditional, biodiversity-related knowledge systems with the aim of integrating it into appropriate scientific conservation models to hone the conservation efforts of Ghana's biodiversity. This document was skillfully put together via a thorough research with the sole aim of offering a solution to this dearth in the traditional knowledge of conservation in Ghana.

This traditional biodiversity strategy is not a substitute to the existing biodiversity-related policies in this nation. Rather, it is a clear and easy guide to the great worth of conservation ethos in the unmatched cultural and artistic elements of the Ghanaian people. It is to serve as an alternative in beefing up the often neglected traditional knowledge systems in the existing biodiversity-related policies and strategies in Ghana. The document shows practical and efficient ways that the traditional knowledge systems in Ghana could be harnessed in heightening conservation efforts in Ghana to avert the biodiversity menace in Ghana. It offers a clear and explicit guide to project officers and conservationists in the field on how to bolster conservation efforts using the traditional knowledge systems evident in the cultural and artistic elements of the Ghanaian people.

As said earlier, this traditional conservation strategy is a complement to the scientific conservation models used in Ghana. This document is a product of the phenomenological study earlier conducted by the researcher (Refer to Adom et al., 2018). As such, each of the components of the strategy shows which aspect of the scientific strategy or existing biodiversity policy or strategy it is complementing. All aspects of the strategy that have been formulated by the present researcher, espouse the dictates of international conventions and treaties that Ghana has signed and ratified related to traditional ecological knowledge. The conventions and treaties include the Assi Declaration of Religion and Nature (1986), Indigenous and Tribal Peoples Convention (1989), 1992 United Nations Conference on Environment and Development, Agenda 21 United Nations Decade for Sustainable Development (UNDESD, 2005-2014), Desertification Convention (1995), the Strategic Plan for Biodiversity 2011-2020 and the AICHI Biodiversity Targets and the UN Declaration of the Rights of Indigenous People (2006). It also takes cognizance of all existing national legal instruments including the Biosafety Act (2011), Ghana Forest and Wildlife Policy (2012), Forest Protection Decree, 1974 (NRCD 243), Trees and Timber 
Decree, 1974 (NRCD 273), Forest Protection (Amendment) Law, 1986 (PNDCL 142), Forestry Development Master Plan (2016 -2036), Timber Resource Management Act, 1997 (Acts 547), Environmental Assessment Regulation, LI 1652 (1999), National Land Policy (June 1999), Minerals and Mining Act (2006), National Water Policy (2007), Ghana National Climate Change Adaptation Strategy (2010), National Climate Change Policy (2013) and National Environment Policy (2014), the 2002 National Biodiversity Strategy and the 2016 National Biodiversity Strategy and Action Plan. The new, formulated conservation strategy by the writer of this paper, makes great allusions to efficient traditional conservation practices of other global countries and justifies why and how Ghana can utilize them, though, in Ghanaian local contexts in the management of her biodiversity. The National Biodiversity Strategies of countries such as Brazil, Japan, China, India, Tanzania, Kenya and Angola have been referred to in the new strategy formulated by the present researcher for special lessons in traditional biodiversity management in Ghana. The traditional strategy reflects on the humanist ecology that Ghana has now adopted (Ghana NBSAP, 2016), which looks at culture as helping the members in the Ghanaian society to cultivate the needed qualities to play the roles that we have toward nature. As such, the formulated traditional biodiversity strategy utilizes the ideals expressed in the culture theory and the Human-Environment Relation (HER) theory. These theories posit that human cultures, especially, their cultural and artistic elements such as festivals, taboos, cosmological belief systems and so forth exert a great influence on the environment and could be utilized effectively in promoting the conservation of the biodiversity resources in it (Ingold, 1992; Milton, 1996). The formulated traditional biodiversity strategy reveals from the perspective of the owners of the cultural and artistic elements, how they could be harnessed in boosting conservation efforts in the management of biodiversity in Ghana, hence, rooting this developed strategy in the interpretive philosophical paradigm (Angen, 2000). The developed traditional biodiversity strategy is aimed solely at beefing up the existing biodiversity conservation strategy in Ghana by utilizing the cultural conservation values (Mertens, 2007) latent in the cultural and artistic elements of the Ghanaian people (traditional knowledge systems). This is envisioned to result in social change (Silka, 2005), thus, the transformation of the dire state of biodiversity conservation issues in Ghana This justifies the use of the transformative philosophical paradigm in addition to the interpretive philosophical paradigm as the backbone for the development of the traditional conservation strategy.

\subsection{Theoretical Methods}

The development of the traditional biodiversity strategy is solidly based on the phenomenological study (Pietkiewicz \& Smith, 2014) of the cultural and artistic elements in the biodiversity policies and strategies in Ghana. Also, the study highlighted the pivotal roles of cultural and artistic elements like cosmological beliefs, proverbs, taboos, totems and festivals in biodiversity conservation in Ghana. This research design was very appropriate for the study since the study aimed at exploring in great detail (Fraenkel et al., 2012), the implementation of cultural and artistic elements from a 112 purposively and stratified random sample. This sample consisted of Ninety-two (92) of the accessible population consisted of traditional authorities, traditional priests/priestesses, elders in the traditional council, as well as elderly members in the fringe communities with the age of fifty and above availed themselves for the personal interviews and the Focus Group Discussion. Also, fifteen (15) conservationists from the Resource Management and Support Centre (RMSC) of the Forestry Commission, Forestry Research Institute of Ghana (FORIG), Environmental Protection Agency (Ashanti Region), park officers in the Protected Areas for the study as well as five (5) culturists formed part of the accessible population. Focus Group Discussions (Pope et al., 2000), private interviews (Leedy \& Ormrod, 2010) as well as non-participant or complete observer and an observer-as-participant (Kumekpor, 2002; Lacono et al., 2009) were the main data collection instruments used in soliciting the data for the development of the traditional biodiversity strategy. Policy documents, papers and reports on biodiversity in Ghana and other countries were thoroughly reviewed and analyzed via the interpretive document analysis method (Bowen, 2009) to unearth the incorporation and/or relevance of cultural and artistic elements in biodiversity management. The generated data were analysed using the principles in the Interpretative Phenomenological Analysis (Smith \& Osborn, 2008), Interpretive Policy Analysis (Yanow, 2000; Morestin, 2012; Bardach, 2012), and the Conservation Values Analysis of Traditional Knowledge Systems (Smith \& Wishnie, 2000).

\subsection{The Vision and Aim of the Traditional Biodiversity Strategy}

The sole vision and aim of the traditional biodiversity strategy are to expose the astronomical worth of conservation ethos in the cultural and artistic elements of the Ghanaian people to boost conservation efforts of biodiversity in the country. This is to aid in augmenting the efforts achieved in the conservation of biodiversity using the scientific conservation models. It is also aimed at fulfilling Ghana's international obligations in the global biodiversity conventions she has signed and ratified. The vision and aim of the traditional biodiversity strategy partly reflects the vision of the 2016 National Biodiversity Strategy in Ghana, the ninth guiding 
principle in the NBSAP of Tanzania and the article 18 of the Strategic Plan for Biodiversity 2011-2020 and the Aichi targets, all calling for a recognition and integration of traditional knowledge systems in biodiversity conservation for the general good of all citizenry of a country. Therefore, the vision of this traditional biodiversity strategy is to:

'Offer a clear direction on how to utilize the Ghanaian traditional knowledge systems in the cultural and artistic elements of the Ghanaian people in boosting the conservation of biodiversity while serving as a viable complement to the existing scientific conservation models so that the traditional knowledge, cultural practices and innovation would be recognized, respected, and its integration enhanced in modern biodiversity conservation efforts in Ghana to ensure equitable sharing of costs and benefits accrued for the wellbeing, prosperity and security of all Ghanaians.'

The Traditional Biodiversity Strategy is aimed at 'developing innovative strategies for adapting the cultural and artistic elements in Ghana as a viable complement to the scientific conservation models such that these traditional knowledge systems are recognized, respected and integrated into biodiversity management in Ghana.'

\subsection{The Guiding Principles of the Traditional Biodiversity Strategy}

The development of the traditional biodiversity strategy is underpinned and supported by various theories in traditional knowledge systems and the quintessential roles they play in biodiversity management. The ten theories that undergird the developed traditional biodiversity strategy are:

- Integrating traditional knowledge systems into the planning and management of biodiversity provides practical lessons in addressing the current and future challenges associated with biodiversity (Infield \& Mugisha, 2013).

- Traditional Knowledge Systems such as taboos, cosmological belief systems, myths, folklore have a high impact on the management and conservation of biodiversity in the face of modernity (Adom, Kquofi \& Asante, 2016).

- A culture-driven management and conservation strategy for biodiversity has been endorsed to be very successful because of its promotion of social inclusiveness, resilience, cooperation and innovation in local communities (UNESCO, 2012).

- The cultural and artistic elements in most African communities are environmentally-friendly, sustainable, prevent resource exploitation and have contributed greatly to biodiversity conservation (IIED, 1992; Kenya NBSAP, 2000; UNESCO, 2003).

- A truncated approach to the use of only scientific conservation models would not achieve the maximum successes in biodiversity conservation (Golo \& Yaro, 2013; Sinclair, Tuke \& Opiang, 2010).

- Traditional Knowledge systems possess robust behavioural corrective elements and create a strong moral economy for society members in advancing the course of the humanist approach to biodiversity conservation, inciting them in pursuing bio-friendly activities (Materer, Valdivia \& Gilles, 2002).

- Indigenous flora and fauna species and rich habitats of biodiversity have been intertwined in customs, cultural beliefs and practices to ensure their conservation and sustainable use in may societies globally (Wilder, O'meara, Monti \& Nabhan, 2016).

- Traditional knowledge systems have scientific philosophical underpinnings that are in harmony with the scientific conservation models for biodiversity conservation (Awuah-Nyamekye, 2013; Adom, 2016a).

- Integration of both scientific and traditional knowledge systems provide a pluralistic, holistic and more flexible approach and better results in addressing the challenges in biodiversity conservation (Sinclair et al. 2010; Attuquayefio \& Fobil, 2005; Johnson, 1992; Wilder et al. 2016).

- Scientific conservation models and traditional conservation practices must be seen as complements and co-equals with no devaluing of each of the streams of knowledge with the recognition that each possesses distinct elements and values relevant to biodiversity conservation (Ajani, Mgbenka \& Okeke, 2013; Berkes, 2012; Msuya \& Kideghesho, 2009; Iyoro \& Ogungbo, 2013).

\subsection{The Main Objectives of the Traditional Biodiversity Strategy}

The following six strategic objectives of the traditional biodiversity strategy would help Ghana to fully fulfil her international and national obligations regarding the integration of traditional knowledge systems in biodiversity conservation programmes and activities: 
1) to innovatively utilize taboo systems in addressing the challenges in the depletion of threatened species in Ghana;

2) to strategically adapt all traditional festivals in Ghana as occasions for engaging in environmentally-friendly activities that bolster conservation efforts in Ghana;

3) to creatively build on the cosmological belief systems of the Ghanaian people in promoting conservation interests of biodiversity in Ghana;

4) to create public awareness, sensitization and education on the value of traditional biodiversity conservation, restoration and sustainable usage using the proverbs in Ghana;

5) to ensure the active involvement and formalization of the owners of biodiversity and traditional knowledge systems in the formulation of policies, strategies and programmes on biodiversity conservation while ensuring fair and equitable distribution and rewards on the proceeds of biodiversity

6) to provide the needed education to fill the knowledge deficiencies in the use of cultural and artistic elements in biodiversity conservation among conservationists in Ghana as well as intensifying the education of scientific conservation practices in local communities

\section{The Key Components of the Traditional Biodiversity Strategy}

The traditional biodiversity strategy has six (6) components with seventeen (17) action plans, enumerated and elaborated in the subsequent sections.

\subsection{COMPONENT 1: Innovatively utilizing taboo systems in addressing the challenges with the depletion of threatened species in Ghana}

Taboo systems have existed in Ghana for several centuries. They are very effective traditional institutions that have conserved many of the biological diversities in their pristine forms in Ghana. They are strong prohibitions that society members are supposed to observe. They offer the dos and donts in the Ghanaian society. Taboos serve as traditional checks and balances (Diawuo \& Issifu, 2015) and act as viable ethical instruments for ensuring the good link between Ghanaians and their environment (Ababio, 2014). Rim-Rukeh, Irerhievwie and Agbozu (2013) opine that taboos have been the sole factor that has prevented abuse of resources and maintained the buoyancy of the biodiversity in Ghana. The numerous sacred groves and other Protected Areas have been conserved as a result of the taboo systems. The efficiency of taboos in the conservation of biodiversity is partly shrouded in its spiritual and physical consequences (Boateng, 1998; Asante, Adom \& Arthur, 2017).

Also, taboos have metaphysical openness and overridability (Osei, 2006) making it possible to set new taboos and revise existing taboos to reflect the current thinking and use in the Ghanaian society. For instance, new taboos can be set to ban the use of all threatened species of flora and fauna in Ghana. Interestingly, the taboos set on particular biodiversity resources, the taboo days and closed seasons have ecological and scientific relevance to the conservation of biodiversity (Adom, Kquofi \& Asante, 2016; Boamah, 2015). The globally successful countries in biodiversity conservation mentioned earlier have effectively utilized taboo systems. For instance, the biodiversity in many of the sacred groves in Kenya has been regulated by taboo systems (Infield \& Mugisha, 2013). Likewise, China heavily relies on taboo systems in managing their sacred forests, mountains and water bodies (Xue, 2008; Adom, 2016b). Due to the strong impact of taboos in many forest fringe communities, it is imperative that Ghana utilizes it innovatively as have been done by other countries in promoting the conservation of biodiversity in Ghana. The suggested action plans 1-3 of the researcher's developed traditional biodiversity strategy are presented in Appendix 1. They illustrate effective ways that taboos can be used in modern Ghana to heighten conservation efforts for biodiversity.

\subsection{COMPONENT 2: Strategically adapting all traditional festivals in Ghana as occasions for engaging in environmentally friendly activities that bolster conservation efforts in Ghana}

Traditional festivals are important cultural events that elucidate the rich historical and iconic events of celebrant communities (O'Suvillan \& Jackson, 2002). They are organized in lieu of venerating the ancestors and their great achievements that aided in the survival as well as the development of their societies. That notwithstanding, festivals are great events that exemplify the engagement in environmental activities that ensure the conservation of biodiversity in the host communities. During the event, Asante, Adom and Arthur (2017) contend that host communities engage in environmentally healthy activities such as massive cleaning of households and streets of the town, desilting of choked gutters, sweeping, planting of trees (Bonye, 2007), clearing of debris and all forms of refuse to maintain their place identity (Crespi \& Richards, 2007) and honour the ancestors who are believed to visit the people during such occasions (Adom, 2016a). Aside from the environmentally friendly activities that 
lead to biodiversity conservation engaged in by local people during the festive celebrations, special gazette areas of sacred importance are earmarked for the celebrations. These sacred forests and groves are uniquely tied to the traditional festival observance. For instance, the Opemso festival of the Asantes of Anyinam-Kokofu is tied to the Kwantakese sacred grove, the Papa Nantwi Festival of the Kumawu people is associated with the Bomfobiri Wildlife Sanctuary and the Nkyiridwo festival of the people of Essumeja is linked to the Asantemanso Sacred Grove. Thus, the promotion of these traditional festivals in Ghana ensures the reaffirmation of the cultural beliefs that led to the earmarking of such spots as sacrosanct and lead to the protection of the areas from any form of encroachment. These sacred sites are hotspots for rich diversities of biological diversity in their pristine forms due to their perpetual conservation.

Traditional festivals are often characterized by competitions (Fallasi, 1987) which can be tailored to promote traditional conservation knowledge of biodiversity. Instead of the usual beauty pageants that are the usual feature of most traditional festivals, these competitions could be enhanced to instil biodiversity conservation ethos in community members as well as the numerous visitors who attend the event. Also, the traditional festivals could be used as events for awarding personalities of biodiversity conservation who engage in bio-friendly activities in the society to serve as shining examples for others to emulate. In addition, traditional festivals are events in which policy makers and government officials highlight the policies of governments, while companies use it as platforms in showcasing their products and services (Odotei, 2002). Thus, conservation agencies should grasp traditional festivals as occasions to intensify biodiversity conservation education and engage in environmentally friendly activities. This great opportunity is not being well utilized by many countries to promote the conservation of biodiversity (O'Suvillan \& Jackson, 2002).

Globally, festivals are recognized as viable platforms when the ideas of conservation of biodiversity can be espoused. This explains why the United Nations have instituted various festivals for the environment (World Environment Day), the forests (International Day of Forests), wildlife (World Wildlife Day), biodiversity (International Day for Biological Diversity) and other important natural resources in our environment. Therefore, it is a step in the right direction, and a wise course to utilize traditional festivals innovatively to promote biodiversity conservation awareness and activities. This wonderful initiative has been embraced by many countries of the world. For instance, Cudny (2013) noted of the Slovakians that they celebrate the International Festival of Sustainable Development aimed at the sustainable development of the natural resources. Likewise, the Wlodzimierz Puchalski International Festival of Nature Films commemorated in Poland annually as well as the International Environmental Film and Video Festival in Brazil are all geared purposely to environmental protection. Therefore, if traditional festivals are carefully planned, they can be used as great occasions to bolster conservation of biodiversity in the host and surrounding communities. Appendix 2 shows the action plans 4-6 of the developed traditional biodiversity strategy by the researcher on innovative ways of utilizing traditional festivals to boost conservation efforts for biodiversity in Ghana.

\subsection{COMPONENT 3: Creatively building on the cosmological belief systems of the Ghanaian people in promoting conservation interests of biodiversity in Ghana}

Ghanaians believe that hosts of spirits surround them in the universe. Gumo, Gisege, Raballah and Ouma (2012) admit that many African spiritualists believe that humanity lives in a religious universe where everything in the cosmos such as trees, plants, animals and so forth are intimately associated with the Supreme Deity. Thus, they believe in the existence and outworking of many spiritual beings in the cosmos or universe. Thus, Ghanaians believe in the existence of the Supreme Deity, Ancestors, Deities/Spirits, Animism and Sorcery and Witchcraft. Interestingly, all these powers are believed to abhor and punish individuals who engage in environmentally unfriendly activities (Boamah, 2015). Thus, these cosmological belief systems are a powerful source for nature conservation and protection (Chalk, 2006). For instance, the Supreme Deity is believed by Ghanaians as withholding His blessings to individuals, families and societies who engage in negative environmental activities that wantonly destroy the biodiversity resources in their environment (Adom, Kquofi \& Asante, 2016). Likewise, the ancestors and spirits are thought to abhor individuals who mismanage and unsustainably use the biodiversity resources in nature (Taringa, 2006). Many plant species, water bodies and particular spots are affiliated to and/or viewed as abodes of known ancestors and spirits in several Ghanaian societies (Kehinde, 2013). Awuah-Nyamekye (2013) is optimistic that the cosmological belief systems still exert a great influence on Ghanaians and regulate their behaviour favourably towards the biodiversity resources in the environment. Iyoro and Ogungbo (2013) contend that the cosmological belief systems monitor the behaviours of those who believe in them to live in harmony with nature. Soini and Dessein (2016) argue that the cosmological belief systems have behavioural corrective elements that imbue a responsibility in individuals and instil in them conservation values to live in harmony with the biodiversity resources in nature. Indeed, Witoszek (2008) was not far from the 
truth when she theorized that the transformations in attitudes of people which conservationists want to realize cannot happen and survive without searching for solutions in the values and beliefs of local communities.

Cosmological belief systems held by Ghanaians assist them to cultivate biodiversity conservation ethos. In biodiversity conservation education and awareness campaigns, conservation bodies can appeal to the moral inclinations of Ghanaians through the cosmological beliefs that they hold. The reverential fear and respect that many Ghanaians have for the ancestors and spirits can be effectively utilized for the preservation of particular plant and animal species that are seen as endemic and/or threatened. These species could be affiliated to the highly revered spirits and/or ancestors in particular societies in Ghana. Hedlund-de Witt (2013) was right when he theorized that cosmological belief systems have the potential of complementing less sustainable policies for biodiversity conservation and environmental protection. This indicates that cosmological belief systems hold a great potential in promoting biodiversity conservation in Ghana. Appendix 3 illustrates the seventh and eighth action plans of the developed traditional biodiversity strategy by the researcher. It showcases the proactive ways of using the cosmological belief systems of the Ghanaian people in heightening biodiversity conservation.

2.4 COMPONENT 4: Creating public awareness, sensitizing and educating on the value of traditional
biodiversity conservation, restoration and sustainable usage using the proverbs in Ghana

Proverbs are powerful mediums for instructing people on issues such as biodiversity conservation. Gadzekpo (2013) realized the truism in this when she pointed out that many scholars are now realizing the great worth of traditional conservation epistemologies in proverbs that could inculcate the values of sustainable use of biodiversity in individuals. Proverbs offer sound moral lessons that embolden the exhibition of good traits such as living in harmony with nature (Anderson, 2015) while frowning on morally degrading attitudes such as the unbridled use and destruction of biodiversity (Sanauddin, 2015). Ghanaians have rich sources of proverbs that are usually in the preserve of the elderly members in the Ghanaian society. The folk sages in many Ghanaian local communities usually use every opportunity they get with the youth to instruct them on these wise and insightful maxims that exert a positive impact on their behavioural development (Adom, 2014; Rasul, 2015). Therefore, there is the urgent need to look for ways of innovatively using the great oasis of traditional conservation ethos latent in Ghanaian proverbs to promote biodiversity conservation education, sensitization and awareness campaigns. To aid in arresting the biodiversity menace in Ghanaian societies, the negative and unrestrained behavioural patterns of the Ghanaian citizens toward the use of biodiversity resources must be changed (Attuquayefio \& Fobil, 2005). Ghanaian proverbs have the capabilities of transforming these foul behaviours of Ghanaians that do not augur well for biodiversity conservation (Gadzekpo, 2013).

Interestingly, Ghanaian proverbs use metaphoric representations of biodiversity resources such as plants, animals and river bodies as the main characters in relaying the wise axioms. Ghanaian proverbs also demonstrate that a unique, harmonious interpersonal relationship exists between human beings and the biodiversity resources in nature and this must not be marred by the activities of the former. Due to the archetypical roles of Ghanaian proverbs in inciting people toward good behavioural attitudes, Awuah-Nyamekye (2013) is very convinced that it is a great potential asset that could be adapted in the modern quest for enhancing and promoting biodiversity education and sensitization in Ghana. The action plans 9-11 of the developed traditional biodiversity strategy by the researcher point out the avenues that can be used to promote and develop the conservation ethos espoused in Proverbs for biodiversity conservation (Appendix 4).

2.5 COMPONENT 5: Ensuring the active involvement and formalization of the owners of biodiversity and guardians of traditional knowledge systems in the formulation and implementation of policies, strategies and programmes on biodiversity conservation while ensuring fair and equitable distribution and rewards on the proceeds of biodiversity

Local people are important stakeholders in the use and management of biodiversity (De Koninck, 2005). As owners of the lands that house the rich biological diversities in the environment, they are supposed to be rightfully and actively involved in the planning, formulation and implementation of all strategies and policies in biodiversity management. Kehinde (2013) strongly posits that in ensuring successful biodiversity management in societies, local community members must be actively and fully involved in all the planning and decision-making processes. This is crucial because the local people have great and very useful dynamic insight, skills and experiential traditional knowledge in the conservation of biodiversity (Warren, 1991). The United States Environmental Protection Agency (2002) has recognized that when local people are actively involved in all stages of the biodiversity management, it results in richer plans and greater success in the implementation of the biodiversity policy or programme. When the traditional authorities in local regions are empowered and given the privilege of managing biodiversity, there are heightened successes (Breuer, 2002). In Ghana, the introduction of 
Community Forest Committees (CFC) and Community Resource Management Areas (CREMA) are laudable strategies for enhancing local community participation in biodiversity issues.

Unfortunately, the powers of such local associations are limited and not recognized in decision-making processes at the higher level of biodiversity management (Asare, 2000). The Ghana Forest Watch (2006) mentions that the selection of members to these local associations have been biased, rendering it less effective in representing the voices of local people in biodiversity management at the national level. Schultz (2002) opines that better decisions of management plans for biodiversity as well as its implementation pivots on the active involvement of local people as well as their traditional conservation knowledge in the use of biodiversity.

Also, the local people are more determined to positively assist in achieving the conservation of biodiversity and assisting in the implementation of biodiversity policies when they equitably enjoy some of the biodiversity proceeds (Amanor, 2002). When the local communities are well catered for in the equitable sharing of biodiversity proceeds, it would prevent them from engaging and supporting bad environmental activities that destroy the biodiversity in the environment (Teye, 2008) usually driven by their impoverished conditions (Marfo, 2012). Therefore, to improve and yield better results in biodiversity conservation in Ghana, the owners of biodiversity and guardians of the traditional knowledge systems need to be actively involved in all the plans and programmes related to biodiversity management at all levels. There should be an enhanced strategy for ensuring the fair and equitable distribution of biodiversity proceeds to the local communities. This would encourage them in supporting biodiversity conservation initiatives and the implementation of biodiversity conservation strategies in their local regions. What the researcher means, for example, is that, when conservation strategies are being drawn, stakeholders from forest fringe communities must be invited to participate in drawing the strategies. Otherwise, the implementation of the policies cannot be fully successful, as already noted. The action plans 12-14 of the researcher's developed traditional biodiversity strategy show how local communities should be actively involved in the development of biodiversity strategies (Appendix 5).

2.6 COMPONENT 6: Providing the needed education to fill the knowledge deficiencies in the use of cultural and artistic elements in biodiversity conservation among conservationists in Ghana as well as intensifying the education of scientific conservation practices in local communities

In the search for solutions to solve the biodiversity menace, many scholars are of the strong conviction that a synergy of scientific conservation practices and traditional knowledge systems may offer a more constructive approach to biodiversity management (Sinclair, Tuke \& Opiang, 2010; Johnson, 1992; Wilder et al. 2016). Each of the two streams of knowledge has its distinct importance in biodiversity management and conservation. However, when each of the knowledge systems is used single-handedly, Golo and Yaro (2013) contend that it would not yield efficient outcomes in biodiversity conservation. Johnson (1992) concurs that when scientific conservation practices or traditional conservation practices operate in a truncated fashion, they are not likely to achieve maximum benefits. In truism, both traditional conservation practices and scientific conservation practices have their unique strengths and weaknesses. Thus, blending the good components of both conservation practices would result in more successful biodiversity management (Johnson, 1992; Moller et al., 2004). Attuquayefio and Fobil (2005) note of the use of both conservation practices as widening the conservation repertoire, offering a broader solution to the often multi-faceted challenges in biodiversity conservation, using the case of Ghana. Admittedly, there are slight differences in the scientific conservation approaches and the traditional conservation practices. As a result, some scholars are uncertain of the possibility of collaboration between the two streams of knowledge (Awuah-Nyamekye, 2013; Sinclair et al., 2010). Yet, critical studies into the two conservation aspects of knowledge show that the collaborative approach in using scientific conservation models and traditional conservation practices is very feasible. Awuah-Nyamekye (2013) realized that many of the traditional knowledge systems have scientific underpinnings. The problem is how the holders of each of the knowledge systems would be helped to understand that each of the two systems of knowledge is somehow deficient. Thus, conservationists who are more knowledgeable and more inclined to the scientific conservation models must be helped to realize the great conservation ethos in the traditional conservation practices.

Likewise, local people who are owners of traditional conservation practices must also be assisted in knowing the great worth of the scientific conservation models in biodiversity conservation. This deep understanding would ensure that both conservation practices are respected. Moreover, addressing these knowledge gaps would foster unity and better understanding between conservationists and local people living in the forest fringe communities. A proper collaborative approach using the two knowledge systems would be successful only if there is mutual understanding (Iyoro \& Ogungbo, 2013). Conservationists must respect traditional conservation practices and view it as worthwhile and local people should not view scientific conservation practices as an overstepping of their long-held traditions (Wilder et al., 2016). Berkes (2012) as well as Msuya and Kideghesho (2009) cautions 
against the deliberate devaluing of each of the two conservation knowledge systems but rather viewing both as equals and complementary to each other. Ajani et al. (2013) insist that the use of traditional conservation practices should not be seen as a substitution to the scientific models and vice versa. They are complementary to each other and not competitors in the modern quest for a proactive solution to arrest the biodiversity menace. India and China have set excellent examples in weaving the traditional ecological knowledge in their cultural and artistic elements with the scientific conservation models. This has been the secret to their marvellous successful feat in biodiversity conservation (China NBSAP, 2011; India NBSAP, 2008).

Ghana requires a robust biodiversity conservation strategy that will innovatively utilize the strengths in the traditional conservation practices and the scientific conservation models. This can only materialize if the two forms of conservation practices are integrated by ensuring that the knowledge inconsistencies and voids of the conservationists in the traditional conservation practices and the local people represented by the traditional authorities in the scientific conservation practices are catered for adequately. The action plans 15-17 of the researcher's developed traditional biodiversity strategy point out exactly what should be done to fill the knowledge gaps of both conservationists and traditional authorities (Appendix 6). That is, effective ways that conservationists can be educated on the conservation ethos in cultural and artistic elements and how they can effectively use them alongside the scientific conservation approaches (see action plan 15 in Appendix 6). On the other hand, Action plan 16 shows how traditional authorities and their local communities can be educated to appreciate the relevance of the scientific conservation approaches to earn their support for their smooth implementation. Action plan 17 shows practically how the often disjointed relationship between conservationists and traditional authorities in local territories can be improved and/or enhanced. This is crucial for the successful collaborative efforts between these two key stakeholders for the efficient management of Ghana's biodiversity.

\section{The Roles of the Implementation Agencies}

This section details the roles that would be played by the various actors and agencies in ensuring the smooth implementation of the traditional biodiversity strategy in the Ghanaian communities.

\subsection{The Environmental Protection Agency (Ministry of Environment, Science, Technology and Innovation)}

This ministry has been legally assigned to oversee all environmental issues in Ghana. Therefore, the overall implementation of the proposed traditional biodiversity strategy would be ensured by this ministry, working through its allied agency, the Environmental Protection Agency. However, this would not be done in isolation, since biodiversity programmes and initiatives would be mainstreamed into the development plans of other sectoral ministries and agencies. The Environmental Protection Agency should set up a board comprising of representatives of all the institutions tasked with defined roles by the developed traditional biodiversity strategy by the researcher. The board will perform oversight duties on the overarching duties of all the implementation agencies and actors suggested by the developed traditional biodiversity strategy.

\subsection{The Forestry Commission, Wildlife Division, Fisheries Commission and the Department of Parks and Gardens}

Biodiversity management in Ghana is directly in the grips of the three instrumental conservation bodies, that is, the Forestry Commission, the Wildlife Division and the Fisheries Commission. The Forestry Commission (FC) oversees all managerial issues regarding the flora species in the country. The FC will take charge of ensuring all flora related implementation processes in the traditional biodiversity strategy such as supplying seedlings of threatened flora species while guiding local communities in Ghana in undertaking tree planting activities in degraded areas in their jurisdiction during festive celebrations. The Wildlife Division (WD) will educate the local communities on threatened fauna species that need to be conserved via their formulated taboos in their jurisdiction. Also, the WD will take charge of all forms of conservation education in forest fringe communities with the assistance of skilled culturists using proverbs.

The aquatic biodiversity in Ghana is on the other hand, managed by the Fisheries Commission. The Commission must support all activities in local communities, especially communal labour sessions meant to protect and enhance the purity of the water in water bodies and rivers. They must liaise with the traditional authorities in setting local bylaws and taboos against bad fishing practices that negatively affect all aquatic biodiversity.

The Department of Parks and Gardens manages the national parks and other PAs in the country. This agency should work with traditional authorities in forest fringe communities around the parks in educating them against bad environmental practices using the suggested action plans in the developed traditional biodiversity strategy. 


\subsection{The Traditional Authorities}

The traditional authorities in Ghanaian local communities are the owners of the biodiversity in their local Regions. They are also the arbiters in traditional knowledge systems since they are thought to be sitting in the seats of the ancestors. The traditional authorities used herein refer to the chiefs, their cabinet of elders, queen mothers as well as the traditional priests and priestesses. They govern the numerous local communities in Ghana and uphold the traditional knowledge systems. Thus, their role is the fulcrum to the successful implementation of the traditional biodiversity strategy. They must promptly execute their duties in dispensing punishment to persons who flout taboos set to protect biodiversity. They must work with the conservationists in intensifying biodiversity education and awareness campaigns in their jurisdictions via the strategic action plans of the developed traditional biodiversity strategy.

\subsection{The National House of Chiefs and the National Commission on Culture}

This body regulates and monitors the various traditional ruling systems in Ghana. As such, they have a great stake in the governance of chiefs and their cabinets of elders in the local communities. This National House of Chiefs advise the chiefs and their cabinets of elders on salient issues and has the power to call them to order and/or reprimand them when they do not play their duties well. Thus, they would monitor and ensure that the chiefs are meticulously following the dictates outlined in the traditional biodiversity strategy in their jurisdictions. They must send their representatives at regular intervals to local communities to inspect the management of biodiversity. The National House of Chiefs must instruct the various chiefs in submitting regular reports on how they are discharging their implementation duties for perusal and advice.

The National Commission on Culture which is a body interested in the recognition, preservation and promotion of cultural heritage and traditional knowledge systems would be assigned to monitor activities that promote the awareness creation of the relevance of the cultural and artistic elements, particularly, cultural practices and activities that promote biodiversity education as suggested in the developed traditional biodiversity strategy of the researcher.

\subsection{Non-Governmental Agencies in Charge of Biodiversity Management and Conservation in Ghana}

These agencies include the Conservation International, Friends of Water and River Bodies and others whose setups are aimed at protecting the biodiversity resources especially in local Regions of Ghana. They are to ensure that the strategic action plans of the traditional biodiversity strategy receive much recognition in the Ghanaian communities. These NGOs in charge of environmental activities must integrate the clear-cut action plans of the researcher's developed traditional biodiversity strategy into their biodiversity conservation and environmental awareness campaigns.

\subsection{Ghanaian Universities and Institutions of Teaching, Learning and Research in Cultural Studies and Biodiversity Conservation}

The cultural experts and/or lecturers in various institutions of teaching, learning and research in cultural studies would carry out the instruction on cultural and artistic elements pertinent to biodiversity conservation to sensitize conservationists who are not very knowledgeable in traditional knowledge systems on the great conservation wisdom in them. On the other hand, the scientific conservation experts/lecturers in institutions of teaching, learning and research would be tasked to instruct the traditional authorities on the scientific conservation models for biodiversity conservation in these modern times. These forms of education will be carried out through workshops, seminars and short courses organized for the conservationists in their workplaces as well as in local communities for the traditional authorities.

\subsection{Human Resource Experts/ Ministry of Local Government and Rural Development}

This ministry, as well as the human resource experts cited, would be tasked to ensure that local people living in forest fringe communities are employed to assist the conservationists in the protection of the biodiversity resources in their areas. This would deepen their resolve in assisting with biodiversity conservation programmes and activities and restrain them from negative environmental activities that put the country's biodiversity in great danger.

\subsection{Judiciary Service of Ghana, Legal Aid Ghana, Police Service, Law Courts, Forest Guards, Parliament Select Committee on Lands and Forestry and Local Government Service}

These bodies would ensure that the by-laws, taboos and other local laws that promote biodiversity conservation are strengthened and more strictly observed in all the Ghanaian communities. They would work closely with the traditional authorities to ensure stringent observance and adherence to the taboos and cosmological beliefs associated with the use of resources. Also, they would ensure that the right penalties and sanctions are applied to serve as deterrents to other would-be offenders. 


\subsection{Ghana Tourism Authority, Sponsors of Festive Celebrations, Festival Organizing Committees and Export Development and Agric Investment Fund}

As a body interested in the development of tourism in Ghana, the Ghana Tourism Authority would be involved in the planning and management of traditional festivals that would attract tourists into host communities that have highly conserved their biodiversity. Moreover, the body would be tasked with the responsibility of planning developmental schemes to increase the eco-tourism potentials of Protected Areas such as sacred groves and parks that are not populous in the country. This would ensure the protection of these hotspots of biodiversity while generating employment avenues for the impoverished local people living on the fringes of such sites.

Also, the body is to liaise with festive organizing committees and sponsors of festivals to plan and draw effective programmes for festive commemorations that would help to enhance and conserve the biodiversity in the host and their surrounding communities. They would be tasked to find ways of funding the awards that would be given to renowned persons, groups and agencies that have set excellent examples in promoting the conservation of biodiversity in the celebrant communities.

\subsection{Religious Groups and their Leaders}

The religious groups and their leaders would be assigned to promote biodiversity conservation education and activities. They would do this through their religious teachings and programs, using it in inculcating conservation ethos in their followers. They are to support the biodiversity conservation activities in the country through their religious campaigns, capitalizing on the cosmological beliefs held by their followers to promote the conservation of biodiversity.

\subsection{Ministry of Education (Ghana Education Service) and National Council for Curriculum and Development}

These bodies would ensure the full incorporation of traditional knowledge into the curriculum for learners at all levels of education in Ghana. They would also be tasked to oversee educational contests such as quizzes on biodiversity conservation in educational institutions in Ghana.

\subsection{Multi-Media Networks and Communication Media Companies such as Radio Stations, T.V. Stations,} Signage Companies and Information Centres

These media outlets would promote the biodiversity conservation education and awareness campaigns among the general public through the innovative strategies of using the print, video, audio and visual media suggested in the traditional biodiversity strategy.

\section{Conclusions}

The developed traditional biodiversity strategy is to cater for the marginalized inclusion and implicit mention of traditional knowledge systems for conservation in the existing biodiversity-related policies in Ghana. It is hoped that the detailed directions given in this document would serve as a viable complement to the scientific conservation models in the existing biodiversity policies. The document is not to usurp the plans and programs in the existing policies for biodiversity. It is rather addressing the deficiencies in the traditional knowledge component which has been a dire challenge as indicated in the recently released 2016 National Biodiversity Strategy and Action Plan. It is not a conclusive document. It is still a strategic document under development. Thus, it is open to constructive suggestions, inputs, deletions and criticisms that would enhance and improve its efficacy to better serve its sole aims and objectives. The views of experts, conservationists, culturists and researchers in traditional knowledge systems in biodiversity conservation are welcomed. It is the earnest wish of the researcher that this document would play indispensable roles in helping save Ghana's biodiversity, especially, the few remnant biodiversity hotspots in the pristine forest tracts populous in the local regions of Ghana.

\section{References}

Ababio, S. (2014). The Role of Indigenous Beliefs and Cultural Practices For Forest Conservation And Sustainability (Unpublished Thesis, Kumasi). Kwame Nkrumah University of Science and Technology

Adom, D. (2014). General knowledge in art for senior high schools. Kumasi: Adom Series Publications.

Adom, D. (2016a). Asante indigenous knowledge systems: repositories of conservation ethics for Ghana's biodiversity. In Proceedings of the academic conference of Interdisciplinary Approach (Vol. 7, No. 2).

Adom, D. (2016b). Inclusion of Local People and Their Cultural Practices in Biodiversity Conservation: Lessons from Successful Nations. American Journal of Environmental Protection, 4(3), 67-78.

Adom, D., Asante, E. A., Kquofi, S. \& Arthur, N. A. P. (2018). The Conservation Ethos in the Asante Cultural and Artistic Elements for the Management of Ghana's Biodiversity. International Journal of Humanities and Social Science Review, 4(3), 1-22. 
Adom, D., \& Kquofi, S. (2016). The High Impacts of Asante Indigenous Knowledge in Biodiversity Conservation Issues in Ghana: The Case of the Abono and Essumeja Townships in Ashanti Region. British Journal of Environmental Sciences, 4(3), 63-78.

Ajani, E. N., Mgbenka, R. N., \& Okeke, M. N. (2013). Use of Indigenous Knowledge as A Strategy for Climate Change Adaptation among Farmers in Sub-Sahara Africa: Implication For Policy. Asian Journal of Agricultural Extension, Economics \& Sociology, 2(1), 23-40.

Amanor, K. S. (2000). Civil Society Participation in Forestry Policy Dialogue, The Perspective of Farmers. Forest Farming Serie (No. 1, pp. 1-65). Forestry Department, Accra, Ghana.

Anderson, G. (2015). Traditional Akan Ethics: Relevant or Trash to Ghanaians Today? International Journal of Humanities and Social Sciences, 4(1), 7-12.

Angen, M. J. (2000). Evaluating Interpretive Inquiry: Reviewing the Validity Debate and Opening the Dialogue. Qualitative Health Research, 10(3), 378-395

Asante, E. A., Adom, D., \& Arthur, N. A. P. (2017). Promoting Environmental And Infrastructural Development Through Selected Cultural Practices (pp. 561-579). 6th International Conference on Infrastructural Development in Africa.

Asare, A. B. (2000). Operational Guidelines on Community Forest Committees (pp. 6-8). ITTO/ FSD Collaborative off-Reserve Forest Management Project, Resource Management Support Centre, Kumasi.

Attuquayefio, D. K., \& Fobil, J. N. (2005). An Overview of Biodiversity Conservation in Ghana: Challenges and Prospects. West African Journal of Applied Ecology, 7, 1-18.

Awuah-Nyamekye, S. (2013). Managing the Environmental Crisis in Ghana: The Role of African Traditional Religion and Culture- A Case Study Of Berekum Traditional Area. Doctoral Thesis. United Kingdom: University of Leeds.

Bardach, E. (2012). A Practical Guide for Policy Analysis (The Eightfold Path to More Effective Problem Solving, 4th ed.) Washington DC: SAGE Publications

Berkes, F. (2012). Sacred Ecology (3rd ed.). New York: Routledge.

Betsson, C. (2010). Protecting Biodiversity. Retrieved from http://www. Feelfriendly.com

Boamah, A. D. (2015). Akan Indigenous Religio-Cultural Beliefs and Environmental Preservation: The Role Of Taboos. Canada: Queens University.

Boateng, B. A. (1998). Traditional Conservation Practices: Ghana's Example. Institute of African Studies Research Review, 14(1), 42-51

Bonye, Z. S. (2007). Harnessing Synergies: The Role of Traditional Institutions in Natural Resource Management in The Tallensi/Nabdam District Upper East Region (Master's thesis). University of Development Studies, Tamale, Ghana.

Bowen, G. A. (2009). Document analysis as a qualitative research method. Qualitative research journal, 9(2), $27-40$.

Breuer, D. (2002). Community Participation in Local Health and Sustainable Development Approaches and Techniques. European Sustainable Development and Health Series 4, EUR/ICP/POLC.

Chalk, J. R. (2006). Genesis 1-11 and the African worldview: Conflict or Conformity (PhD Thesis). South Africa: University of South Africa.

China NBSAP. (2011). National Biodiversity Strategy and Action Plan. China: Biodiversity Office, SEPA

Crespi, V. M., \& Richards, G. (2007). The Meanings of Cultural Festivals. International Journal of Cultural Policy, 13(1), 103-122.

Cudny, W. (2013). Festival Tourism-The Concept, Key Functions, and Dysfunctions in the Context of Tourism Geography Studies. Geographical Journal, 65, 105-118.

De Koninck, V. (2005). Joint management of Banteng in a Contested Cultural Landscape: Observations and Implications. Human Dimensions of Wildlife, 10(2), 123-135.

Diawuo, F., \& Issifu, A. K. (2015). Exploring the African traditional belief systems in natural resource conservation and management in Ghana. The Journal of Pan African Studies, 8(9), 115-131. 
Fallasi, A. (1987). Festival: Definition and Morphology. In A. Falassi (Ed.), Time Out of Time (pp. 1-10). Albuquerque: University of New Mexico Press.

Fraenkel, J., Wallen, N., \& Hyun, H. (2012). How to Design and Evaluate Research in Education (8th ed.). New York: Mc Graw-Hill Companies

Gadzekpo, A. (2013). Cultural Innovation for Sustainability in Ghana: Back to Proverbial Wisdom. Dubrovnik: Inter University Centre. Retrieved from http://www.ceres21.org

Ghana National Biodiversity Strategy and Action Plan (NBSAP). (2016). National Biodiversity Strategy. Ghana: Ministry of Environment, Science, Technology and Innovation.

Gumo, S., Gisege, S. O., Raballah, E., \& Ouma, C. (2012). Communicating African Spirituality through Ecology: Challenges and Prospects for the 21st Century. Religions, 3, 523-543.

Hedlund-de Witt, A. (2013). Worldviews and the Transformation to Sustainable Societies (PhD Thesis). Amsterdam: Vrije Universiteit Amsterdam.

India NBSAP. (2008). National Biodiversity Strategy and Action Plan. Ministry of Environment, Forests and Climate Change. India: Government of India

Infield, M., \& Mugisha, A. (2013). Culture, values and conservation: a review of perspectives, policies and practices. Fauna \& Flora International, Cambridge UK, 2.

Ingold, T. (1992). Culture and the Perception of the Environment. In E. Croll, \& D. Parkin (Eds.), Bush Base, Forest Farm. London: Routledge

International Institute for Environment and Development (IIED). (1992). Indigenous Knowledge, Biodiversity Conservation and Development. Retrieved from www.iied.org

Johnson, M. (1992). Research on Traditional Knowledge: Its Development and Its Role In M. Johnson (Ed.), Lore: Capturing Traditional Environmental Knowledge (pp. 3-27). Ottawa: International Development Research Centre.

Kehinde, O. (2013). African Religion and Environmental Dynamics. Journal of Studies in Social Sciences, 4(2), $199-212$

Kenyan National Biodiversity Strategy and Action Plan (NBSAP). (2000). Ministry of Environment and Natural Resources. Nairobi-Kenya: The National Environment and Natural Resources.

Kumekpor, K. B. (2002). Research Methods \& Techniques of Social Research. Ghana: SonLife Printing Press and Services.

Lacono, J., Brown, A. P., \& Holtham, C. (2009). Research Methods- A Case Example of Participant Observation. Electronic Journal of Business Research Methods, 7(1), 39-46.

Leedy, P. D., \& Ormrod, J. E. (2010). Practical Research: Planning and Design (9th ed.). Upper Saddle River, New Jersey: Pearson Education, Inc.

Materer, S., Valdivia, C., \& Gilles, J. (2002). Indigenous Knowledge Systems: Characteristics and Importance to Climatic Uncertainty. Department of Agricultural Economics Working Paper No. AEWP 2001-2003. Columbia: University of Missouri.

Mertens, D. M. (2007). Transformative Paradigm: Mixed Methods and Social Justice. Journal of Mixed Methods Research, 1(2), 212-225

Milton, K. (1996). Environmentalism and Culture Theory: Exploring the Role of Anthropology in Environmental Discourse. London: Routledge Taylor and Francis Group.

Moller, H., Berkes, F., Lyver, P. O. B., \& Kislalioglu, M. (2004). Combining science and traditional ecological knowledge: monitoring populations for co-management. Ecology and society, 9(3).

Msuya, T. S., \& Kideghesho, J. R. (2009). The Role of Traditional Management Practices in Enhancing Sustainable Use and Conservation of Medicinal Plants in West Usambara Mountains, Tanzania. Tropical Conservation Science, 2(1), 88-105

Odotei, I. (2002). Festivals in Ghana: Continuity, Transformation, and Politicization of Tradition. Transactions of the Historical Society of Ghana, New Series, 6, 17-34. 
Olaide, I. A., \& Omolere, O. W. (2005). Management of indigenous knowledge as a catalyst towards improved information accessibility to local communities: a literature review. Chin. Librarianship Int. Electron. J, 35, 87-98.

Osei, J. (2006). The Value of African Taboos for Biodiversity and Sustainable Development, Journal of Sustainable Development in Africa, 8(3), 42-61

O'Sullivan, D., \& Jackson, M. J. (2002). Festival Tourism: A Contributor to Sustainable Local Economic Development? Journal of Sustainable Tourism, 10, 325-342. https://doi.org/10.1080/09669580208667171

Pietkiewicz, I., \& Smith, J. A. (2014). A Practical Guide to Using Interpretative Phenomenological Analysis in Qualitative Research Psychology. Psychological Journal, 20(1), 7-14.

Pope, C., Ziebland, S., \& Mays, N. (2000). Qualitative Research: Analysing Qualitative Data. British Medical Journal, 320, 114-116.

Rasul, S. (2015). Gender and Power Relationships in The Language of Proverbs: Image of Woman. FNU Journal of Social Sciences, 9(2).

Rim-Rukeh, A., Irerhievwie, G., \& Agbozu, I. E. (2013). Traditional Beliefs and Conservation of Natural Resources: Evidences from Selected Communities in Delta State, Nigeria. International Journal of Biodiversity Conservation, 5(7), 426-432

Sanauddin, N. (2015). Proverbs and Patriarchy: Analysis of Linguistic Sexism and Gender Relations among the Pashtuns of Pakistan (PhD Thesis). Scotland: University of Glasgow.

Schultz, P. W. (2002). Environmental Attitudes and Behaviours Across Cultures. Online Readings in Psychology and Culture, 8(1). Retrieved from http://dx.doi.org/10.9707/2307.0919.1070

Silka, L. (2005). Building Culturally Competent Research Partnerships. Paper presented at the annual meeting of the American Psychological Association, Washington, DC.

Sinclair, J. R., Tuke, L., \& Opiang, M. (2010). What the Local Know: Comparing Traditional and Scientific Knowledge of Megapodes in Melanesia. In S. Tidemann, A. Gosler, \& R. Gosford (Eds.), Ethno-Ornithology: Global Studies in Indigenous Ornithology: Culture, Society and Conservation. London: Earthscan.

Smith, E. A., \& Wishnie, M. (2000). Conservation and Subsistence in Small-Scale Societies. Annual Reviews Anthropology, 29, 493-524.

Smith, J. A., \& Osborn, M. (2008). Interpretive Phenomenological Analysis. In J. Smith (Ed.), Qualitative Psychology: A Practical Guide to Research Methods. London: SAGE Publications.

Soini, K., \& Dessein, J. (2016). Culture-Sustainability Relation: Towards a Conceptual Framework. Sustainability, 8, 167.

Taringa, N. (2006). How Environmental is African Traditional Religion? Exchange, 35(2), 191-214.

Teye, J. K. (2008). Forest Resource Management in Ghana: An Analysis of Policy and Institutions (Ph.D Thesis). England: The University of Leeds

U.S. E.P.A. (2002). Community, Culture and the Environment, A Guide for Understanding a Sense of Place. Washington DC: United States Environmental Protection Agency.

UNESCO. (2003). Cultural Diversity and Biodiversity for Sustainable Development. Retrieved from http://www.unesco.org

UNESCO. (2012). Culture: A Driver and An Enabler of Sustainable Development. Retrieved from www.un.org $>$ pdf $>2$ culture

Warren, D. M. (1991). Using Indigenous Knowledge in Agricultural Development. World Bank Discussion Paper No.127. Washington DC: The World Bank.

Wilder, B. T., O’Meara, C., Monti, L., \& Nabhan, G. P. (2016). The Importance of Indigenous Knowledge in Curbing the Loss of Language and Biodiversity. BioScience, 66(6), 449-509.

Witoszek, N. (2013). Religion and Ecodmodernity. Oslo: Norwegian University Press.

Xue, D. (2008). Categories of Traditional Knowledge Associated With Protection and Sustainable Use of Biodiversity in Minority Areas of China. College of Life and Environmental Science, Minzu University of China, Beijing.

Yanow, D. (2000). Conducting Interpretive Policy Analysis. Thousand Oaks, California: SAGE Publications 


\section{Appendix 1}

\begin{tabular}{|c|c|c|c|c|c|c|c|}
\hline Strategy (What) & $\begin{array}{l}\text { Target } \\
\text { (How) }\end{array}$ & $\begin{array}{l}\text { The complemented } \\
\text { Scientific } \\
\text { Conservation } \\
\text { Strategies }\end{array}$ & $\begin{array}{l}\text { Affiliated } \\
\text { International } \\
\text { Convention / } \\
\text { National } \\
\text { Legal } \\
\text { instrument / } \\
\text { Lessons from } \\
\text { Other } \\
\text { Countries }\end{array}$ & $\begin{array}{l}\text { Description of } \\
\text { Indicator }\end{array}$ & $\begin{array}{l}\text { Implementation } \\
\text { Agencies/Actors } \\
\text { (Who) }\end{array}$ & $\begin{array}{l}\text { Jurisdiction for } \\
\text { Implementatio } \\
\mathbf{n} \\
\text { (Where) }\end{array}$ & $\begin{array}{l}\text { Frequency } \\
\text { (When) }\end{array}$ \\
\hline \multicolumn{8}{|c|}{$\begin{array}{l}\text { Action Plan 1: Ensure the full observance of all productive and biodiversity-friendly taboos that prevent resource abuse and unrestrained harvesting in Ghanaian } \\
\text { communities }\end{array}$} \\
\hline $\begin{array}{l}\text { Innovatively } \\
\text { utilize taboo } \\
\text { systems in } \\
\text { addressing the } \\
\text { challenges with } \\
\text { the depletion of } \\
\text { threatened species }\end{array}$ & $\begin{array}{l}\text { Strictly observe all } \\
\text { the taboos on sound } \\
\text { environmental } \\
\text { conservation ethics } \\
\text { such as taboos } \\
\text { against the } \\
\text { unrestrained cutting } \\
\text { of trees, bad farming } \\
\text { practices such as } \\
\text { bush burning, etc. }\end{array}$ & $\begin{array}{l}\text { National Bio-Safety } \\
\text { Risk Assessment } \\
\text { Guidelines (NBSAP } \\
2016 \text { ) } \\
\text { Restrict exploitation } \\
\text { of animals and plants } \\
\text { by fixing quotas and } \\
\text { sustainable removal } \\
\text { figures (NBS 2002) }\end{array}$ & $\begin{array}{l}\text { Using taboo } \\
\text { systems in } \\
\text { efficiently } \\
\text { managing the } \\
\text { sacred forests, } \\
\text { mountains and } \\
\text { water bodies in } \\
\text { China (China } \\
\text { NBSAP } \\
\text { 2011-2030) }\end{array}$ & $\begin{array}{l}\text { Taboo systems } \\
\text { used for } \\
\text { biodiversity } \\
\text { conservation } \\
\text { strictly observed }\end{array}$ & $\begin{array}{l}\text { Traditional } \\
\text { Authorities in } \\
\text { local communities } \\
\text { National } \\
\text { Commission on } \\
\text { Culture } \\
\text { Ministry of } \\
\text { Environment, } \\
\text { Science, } \\
\text { Technology and } \\
\text { Innovation } \\
\text { Department of } \\
\text { Parks } \\
\text { Forestry } \\
\text { Commission } \\
\text { Fisheries } \\
\text { Commission }\end{array}$ & $\begin{array}{l}\text { Local } \\
\text { communities } \\
\text { where taboo } \\
\text { systems are very } \\
\text { effective due to } \\
\text { the robust } \\
\text { traditional } \\
\text { governance } \\
\text { systems } \\
\text { Protected Areas } \\
\text { in local Regions } \\
\text { Forest fringe } \\
\text { communities in } \\
\text { local } \\
\text { communities }\end{array}$ & Daily \\
\hline \multirow[t]{2}{*}{$\begin{array}{l}\text { Innovatively } \\
\text { utilize taboo } \\
\text { systems in } \\
\text { addressing the } \\
\text { challenge in the } \\
\text { depletion of } \\
\text { threatened species } \\
\text { from possible } \\
\text { extinction }\end{array}$} & $\begin{array}{l}\text { Properly orient and } \\
\text { instruct visitors who } \\
\text { visit Protected Areas } \\
\text { with eco-tourism } \\
\text { potentials in Ghana } \\
\text { such as Lake } \\
\text { Bosomtwe, } \\
\text { Bomfobiri Wildlife } \\
\text { Sanctuary etc. on the } \\
\text { taboos regarding the } \\
\text { biodiversity resources } \\
\text { in the area. }\end{array}$ & $\begin{array}{l}\text { Promote eco-tourism } \\
\text { development (NBS } \\
\text { 2002) }\end{array}$ & $\begin{array}{l}\text { Tourists/visitor } \\
\mathrm{s} \text { to Protected } \\
\text { Areas must } \\
\text { abide by the } \\
\text { management } \\
\text { and are liable } \\
\text { to pay fees } \\
\text { collected to aid } \\
\text { in the } \\
\text { conservation } \\
\text { of biodiversity } \\
\text { in the area } \\
\text { (Guidance for } \\
\text { planning and } \\
\text { management } \\
\text { of Protected } \\
\text { Areas, WCPA } \\
\text { 2002) }\end{array}$ & $\begin{array}{l}\text { Visitors are } \\
\text { properly } \\
\text { instructed and } \\
\text { oriented on taboos } \\
\text { to be observed in } \\
\text { all Protected } \\
\text { Areas in Ghana }\end{array}$ & $\begin{array}{l}\text { Ghana Tourism } \\
\text { Authority } \\
\text { Forestry } \\
\text { Commission } \\
\text { Wildlife Division } \\
\text { Fisheries } \\
\text { Commission } \\
\text { National } \\
\text { Commission on } \\
\text { Culture } \\
\text { Traditional } \\
\text { Authorities } \\
\text { MESTI }\end{array}$ & $\begin{array}{l}\text { Protected Areas } \\
\text { in Ghana } \\
\text { Eco-Tourism } \\
\text { sites such as } \\
\text { Parks etc. }\end{array}$ & Daily \\
\hline & $\begin{array}{l}\text { Impose and strictly } \\
\text { ensure that penalties } \\
\text { regarding the abuse } \\
\text { of taboos on } \\
\text { biodiversity are duly } \\
\text { paid to serve as a } \\
\text { strong deterrent for } \\
\text { such actions. }\end{array}$ & $\begin{array}{l}\text { Strengthen legal } \\
\text { framework to give } \\
\text { permanence to } \\
\text { Protected Areas in } \\
\text { order to conserve } \\
\text { biodiversity in the } \\
\text { country (GFWP 2012) }\end{array}$ & $\begin{array}{l}\text { Tourists to } \\
\text { Protected } \\
\text { Areas must } \\
\text { abide by the } \\
\text { management in } \\
\text { the } \\
\text { conservation } \\
\text { of biodiversity } \\
\text { (Guidance for } \\
\text { planning and } \\
\text { management } \\
\text { of Protected } \\
\text { Areas, WCPA } \\
\text { 2002) }\end{array}$ & & $\begin{array}{l}\text { Traditional } \\
\text { Authorities } \\
\text { Law Courts } \\
\text { Police Service } \\
\text { Forestry } \\
\text { Commission } \\
\text { Wildlife Division } \\
\text { National } \\
\text { Commission on } \\
\text { Culture }\end{array}$ & $\begin{array}{l}\text { Local } \\
\text { communities } \\
\text { where taboos } \\
\text { have high } \\
\text { impact } \\
\text { Protected Areas } \\
\text { and their forest } \\
\text { fringe } \\
\text { communities }\end{array}$ & Daily \\
\hline
\end{tabular}




\begin{tabular}{|c|c|c|c|c|c|c|c|}
\hline Strategy (What) & $\begin{array}{l}\text { Target } \\
\text { (How) }\end{array}$ & $\begin{array}{l}\text { The complemented } \\
\text { Scientific } \\
\text { Conservation } \\
\text { Strategies }\end{array}$ & $\begin{array}{l}\text { Affiliated } \\
\text { International } \\
\text { Convention / } \\
\text { National } \\
\text { Legal } \\
\text { instrument / } \\
\text { Lessons from } \\
\text { Other } \\
\text { Countries } \\
\end{array}$ & $\begin{array}{l}\text { Description of } \\
\text { Indicator }\end{array}$ & $\begin{array}{l}\text { Implementation } \\
\text { Agencies/Actors } \\
\text { (Who) }\end{array}$ & $\begin{array}{l}\text { Jurisdiction for } \\
\text { Implementatio } \\
\mathbf{n} \\
\text { (Where) }\end{array}$ & $\begin{array}{l}\text { Frequency } \\
\text { (When) }\end{array}$ \\
\hline $\begin{array}{l}\text { Recognize, } \\
\text { promote, observe } \\
\text { and legalize taboo } \\
\text { days and closed } \\
\text { seasons that } \\
\text { protect the } \\
\text { biodiversity } \\
\text { resources in } \\
\text { Ghana }\end{array}$ & $\begin{array}{l}\text { Enact specific laws to } \\
\text { incorporate into } \\
\text { forest laws, the } \\
\text { closed seasons and } \\
\text { taboo days that } \\
\text { ensure the } \\
\text { conservation of } \\
\text { biodiversity }\end{array}$ & $\begin{array}{l}\text { Enact specific legal } \\
\text { provisions in the } \\
\text { management of } \\
\text { Protected Areas } \\
\text { (Ghana FWP 2012) } \\
\text { Traditional laws and } \\
\text { sanctions that promote } \\
\text { biodiversity } \\
\text { conservation should } \\
\text { be accorded legal } \\
\text { backing to ensure } \\
\text { effective enforcement } \\
\text { (NBS 2002) }\end{array}$ & $\begin{array}{l}\text { Set by-laws } \\
\text { that are } \\
\text { efficient for } \\
\text { the } \\
\text { management } \\
\text { of biodiversity } \\
\text { in Protected } \\
\text { Areas } \\
\text { (Guidance for } \\
\text { planning and } \\
\text { management } \\
\text { of Protected } \\
\text { Areas, WCPA } \\
\text { 2002) }\end{array}$ & $\begin{array}{l}\text { Closed seasons } \\
\text { and taboo days } \\
\text { are mainstreamed } \\
\text { into forest laws }\end{array}$ & $\begin{array}{l}\text { Traditional } \\
\text { Authorities } \\
\text { Forestry } \\
\text { Commission } \\
\text { Wildlife Division } \\
\text { Local } \\
\text { Government } \\
\text { Service } \\
\text { Legal Aid Ghana } \\
\text { Judicial Service } \\
\text { of Ghana }\end{array}$ & $\begin{array}{l}\text { Forest Fringed } \\
\text { Communities } \\
\text { Protected Areas }\end{array}$ & Periodically \\
\hline \multicolumn{8}{|c|}{ Action Plan 3: Setting, legalizing and promulgating new taboos to prevent possible extinction of threatened species of biodiversity in Ghana } \\
\hline $\begin{array}{l}\text { Set, legalize and } \\
\text { promulgate new } \\
\text { taboos to prevent } \\
\text { possible } \\
\text { extinction of } \\
\text { threatened species } \\
\text { of biodiversity in } \\
\text { Ghana }\end{array}$ & $\begin{array}{l}\text { Set new taboos } \\
\text { through a consensus } \\
\text { between the } \\
\text { traditional authorities } \\
\text { and conservationists } \\
\text { to avoid the } \\
\text { exploitation of } \\
\text { threatened species in } \\
\text { the IUCN Red List } \\
\text { and in nationally } \\
\text { declared endangered } \\
\text { species by the } \\
\text { conservation } \\
\text { agencies. }\end{array}$ & $\begin{array}{l}\text { Regulation to protect } \\
\text { endangered species } \\
\text { (Ghana NBSAP 2016) } \\
\text { Enforce the ban on all } \\
\text { protected wildlife } \\
\text { species in Ghana } \\
\text { (Ghana FWP 2012) }\end{array}$ & $\begin{array}{l}\text { Prevent the } \\
\text { extinction of } \\
\text { known } \\
\text { threatened } \\
\text { species and } \\
\text { their } \\
\text { conservation } \\
\text { status, } \\
\text { particularly, of } \\
\text { those in high } \\
\text { decline, and } \\
\text { improving and } \\
\text { sustaining their } \\
\text { status } \\
\text { CBD Aichi } \\
\text { Target } 12 \\
\text { (2011-2020) }\end{array}$ & $\begin{array}{l}\text { New taboos set to } \\
\text { avoid exploitation } \\
\text { of threatened } \\
\text { species of } \\
\text { biodiversity in } \\
\text { Ghana }\end{array}$ & $\begin{array}{l}\text { Traditional } \\
\text { Authorities } \\
\text { Forest } \\
\text { Commission } \\
\text { Wildlife Division } \\
\text { Local } \\
\text { Government } \\
\text { Service } \\
\text { Legal Aid Ghana } \\
\text { Judicial Service } \\
\text { of Ghana } \\
\text { Parliamentary } \\
\text { Select Committee } \\
\text { on Lands and } \\
\text { Forestry }\end{array}$ & $\begin{array}{l}\text { Forest fringe } \\
\text { communities in } \\
\text { Ghana } \\
\text { Protected Areas }\end{array}$ & Periodically \\
\hline \multicolumn{8}{|c|}{$\begin{array}{l}\text { Action Plan 4: Engaging in rigorous biodiversity-friendly activities to promote biodiversity conservation and awareness in the host and surrounding communities during the } \\
\text { commemoration of traditional festivals }\end{array}$} \\
\hline $\begin{array}{l}\text { Engage in } \\
\text { rigorous healthy } \\
\text { and bio-friendly } \\
\text { environmental } \\
\text { activities to } \\
\text { promote and } \\
\text { enhance the } \\
\text { conservation of } \\
\text { biodiversity in the } \\
\text { host and } \\
\text { surrounding } \\
\text { communities }\end{array}$ & $\begin{array}{l}\text { Undertake massive } \\
\text { tree planting } \\
\text { exercises in degraded } \\
\text { areas of Protected } \\
\text { Areas and/or in the } \\
\text { host communities as } \\
\text { well as de-silt and } \\
\text { clean all water bodies } \\
\text { through the } \\
\text { traditional festival }\end{array}$ & $\begin{array}{l}\text { Restoration of } \\
\text { degraded eco-systems } \\
\text { through community } \\
\text { efforts and community } \\
\text { nurseries } \\
\text { (Ghana NBSAP 2016) } \\
\text { Increasing forest and } \\
\text { tree cover through } \\
\text { afforestation and } \\
\text { reforestation } \\
\text { Using Farm Boundary } \\
\text { Planting, Agroforestry } \\
\text { Systems and } \\
\text { Enrichment Planting } \\
\text { (Ghana WFP 2012) }\end{array}$ & $\begin{array}{l}\text { Indigenous } \\
\text { people have } \\
\text { the right to } \\
\text { manifest, } \\
\text { practice, } \\
\text { develop and } \\
\text { teach their } \\
\text { spiritual and } \\
\text { religious, } \\
\text { customs and } \\
\text { ceremonies } \\
\text { regarding } \\
\text { sacred sites } \\
\text { (UNDRIP } \\
\text { 2006, Article } \\
\text { 12) }\end{array}$ & $\begin{array}{l}\text { Degraded areas of } \\
\text { Protected Areas } \\
\text { and in special } \\
\text { areas of host } \\
\text { communities are } \\
\text { planted with trees } \\
\text { and their water } \\
\text { bodies cleansed } \\
\text { (under the } \\
\text { auspices of the } \\
\text { Forestry } \\
\text { Commission) }\end{array}$ & $\begin{array}{l}\text { Traditional } \\
\text { Authorities } \\
\text { Festival Organizing } \\
\text { Committees } \\
\text { Non-Governmental } \\
\text { Organizations for } \\
\text { Conservation } \\
\text { (Conservation } \\
\text { International, Friends } \\
\text { of Rivers and Water } \\
\text { Bodies) } \\
\text { Environmental } \\
\text { Protection Agency } \\
\text { Water and Sanitation } \\
\text { Agency, Ghana } \\
\text { Tourism Authority }\end{array}$ & $\begin{array}{l}\text { Traditional } \\
\text { festival host } \\
\text { communities } \\
\text { and their } \\
\text { surrounding } \\
\text { communities }\end{array}$ & Annually \\
\hline
\end{tabular}




\begin{tabular}{|c|c|c|c|c|c|c|c|}
\hline Strategy (What) & $\begin{array}{l}\text { Target } \\
\text { (How) }\end{array}$ & $\begin{array}{l}\text { The complemented } \\
\text { Scientific } \\
\text { Conservation } \\
\text { Strategies }\end{array}$ & $\begin{array}{l}\text { Affiliated } \\
\text { International } \\
\text { Convention / } \\
\text { National } \\
\text { Legal } \\
\text { instrument / } \\
\text { Lessons from } \\
\text { Other } \\
\text { Countries }\end{array}$ & $\begin{array}{l}\text { Description of } \\
\text { Indicator }\end{array}$ & $\begin{array}{l}\text { Implementation } \\
\text { Agencies/Actors } \\
\text { (Who) }\end{array}$ & $\begin{array}{l}\text { Jurisdiction for } \\
\text { Implementatio } \\
\mathbf{n} \\
\text { (Where) }\end{array}$ & $\begin{array}{l}\text { Frequency } \\
\text { (When) }\end{array}$ \\
\hline & $\begin{array}{l}\text { Involve local } \\
\text { communities in } \\
\text { identifying areas of } \\
\text { priority in } \\
\text { biodiversity } \\
\text { conservation and } \\
\text { management }\end{array}$ & $\begin{array}{l}\text { Effectively empower } \\
\text { and solicit for the } \\
\text { support of the youth in } \\
\text { the sustainable } \\
\text { management of } \\
\text { biodiversity } \\
\text { (NBS 2002) }\end{array}$ & $\begin{array}{l}\text { Involving local } \\
\text { communities } \\
\text { in the } \\
\text { identification } \\
\text { of priority } \\
\text { areas of } \\
\text { biodiversity } \\
\text { (Tanzania } \\
\text { NBSAP 2001) }\end{array}$ & $\begin{array}{l}\text { Local } \\
\text { communities are } \\
\text { involved in the } \\
\text { identification of } \\
\text { priority areas for } \\
\text { biodiversity } \\
\text { conservation }\end{array}$ & & $\begin{array}{l}\text { Traditional } \\
\text { festivals host } \\
\text { communities } \\
\text { and their } \\
\text { surrounding } \\
\text { communities }\end{array}$ & Periodically \\
\hline $\begin{array}{l}\text { Engage in } \\
\text { rigorous healthy } \\
\text { and bio-friendly } \\
\text { environmental } \\
\text { activities to } \\
\text { promote and } \\
\text { enhance the } \\
\text { conservation of } \\
\text { biodiversity in the } \\
\text { festival host and } \\
\text { surrounding } \\
\text { communities. }\end{array}$ & $\begin{array}{l}\text { Assign conservation } \\
\text { projects to youth or } \\
\text { children groups in } \\
\text { host communities } \\
\text { during the festival } \\
\text { eve and award them } \\
\text { with prices to imbibe } \\
\text { in them conservation } \\
\text { ethos for biodiversity }\end{array}$ & & $\begin{array}{l}\text { Promoting } \\
\text { Children } \\
\text { Waterfront } \\
\text { rediscovery } \\
\text { project to } \\
\text { increase } \\
\text { opportunities } \\
\text { for children in } \\
\text { local } \\
\text { communities } \\
\text { (Japan NBSAP } \\
\text { 2012-2020) }\end{array}$ & $\begin{array}{l}\text { Youth and } \\
\text { children groups in } \\
\text { local communities } \\
\text { are assigned } \\
\text { conservation } \\
\text { projects during } \\
\text { festival occasions } \\
\text { and are awarded } \\
\text { duly }\end{array}$ & $\begin{array}{l}\text { Sponsors of the } \\
\text { Traditional } \\
\text { Festivals }\end{array}$ & $\begin{array}{l}\text { Traditional } \\
\text { festivals host } \\
\text { communities } \\
\text { and their } \\
\text { surrounding } \\
\text { communities }\end{array}$ & Periodically \\
\hline \multicolumn{8}{|c|}{$\begin{array}{l}\text { Action Plan 5: Effectively plan traditional festival program to include biodiversity education and awareness to facilitate better commitment of community members to } \\
\text { biodiversity conservation }\end{array}$} \\
\hline $\begin{array}{l}\text { Tactfully plan the } \\
\text { programs of } \\
\text { traditional } \\
\text { festivals to } \\
\text { increase } \\
\text { biodiversity } \\
\text { conservation } \\
\text { education, } \\
\text { sensitization and } \\
\text { awareness in host } \\
\text { communities }\end{array}$ & $\begin{array}{l}\text { Organize } \\
\text { competitions during } \\
\text { the festival event on } \\
\text { biodiversity-related } \\
\text { traditional knowledge } \\
\text { systems to increase } \\
\text { biodiversity } \\
\text { conservation } \\
\text { education }\end{array}$ & $\begin{array}{l}\text { Collaborate with } \\
\text { community-based } \\
\text { organizations and } \\
\text { NGOs in } \\
\text { implementing } \\
\text { programs that seek to } \\
\text { intensify national } \\
\text { awareness campaign } \\
\text { on the conservation of } \\
\text { wildlife and forest } \\
\text { resources in Ghana } \\
\text { (Ghana FWP 2012) }\end{array}$ & $\begin{array}{l}\text { Establish and } \\
\text { promote } \\
\text { appropriate } \\
\text { education and } \\
\text { awareness } \\
\text { programs to } \\
\text { facilitate proper } \\
\text { community } \\
\text { participation in } \\
\text { the conservation } \\
\text { of biodiversity } \\
\text { (Tanzania } \\
\text { NBSAP 2001) }\end{array}$ & $\begin{array}{l}\text { Competitions on } \\
\text { biodiversity-relate } \\
\mathrm{d} \text { traditional } \\
\text { knowledge } \\
\text { systems organized } \\
\text { during the festival } \\
\text { observance in } \\
\text { host communities }\end{array}$ & $\begin{array}{l}\text { Forestry Commission } \\
\text { Traditional } \\
\text { Authorities } \\
\text { Festival Organizing } \\
\text { Committees } \\
\text { Non-Governmental } \\
\text { Organizations for } \\
\text { Conservation } \\
\text { (Conservation } \\
\text { International, Friends } \\
\text { of Rivers and Water } \\
\text { Bodies) } \\
\text { Department of Parks }\end{array}$ & $\begin{array}{l}\text { Host } \\
\text { communities of } \\
\text { traditional } \\
\text { festivals and } \\
\text { their } \\
\text { surrounding } \\
\text { communities }\end{array}$ & Annually \\
\hline $\begin{array}{l}\text { Tactfully plan the } \\
\text { programs of } \\
\text { traditional } \\
\text { festivals to } \\
\text { increase } \\
\text { biodiversity } \\
\text { conservation } \\
\text { education, } \\
\text { sensitization and } \\
\text { awareness in host } \\
\text { communities }\end{array}$ & $\begin{array}{l}\text { Reward individuals, } \\
\text { groups and } \\
\text { companies that } \\
\text { engage in activities } \\
\text { that ensure } \\
\text { biodiversity } \\
\text { conservation in the } \\
\text { Region during the } \\
\text { commemoration of } \\
\text { traditional festivals }\end{array}$ & $\begin{array}{l}\text { Develop and } \\
\text { implement a } \\
\text { community-based } \\
\text { incentive reward } \\
\text { system for ecosystem } \\
\text { services (NBSAP } \\
2016 \text { ) } \\
\text { Show recognition for } \\
\text { activities undertaken } \\
\text { by individuals, } \\
\text { corporate bodies and } \\
\text { communities in the } \\
\text { sustainable use of } \\
\text { biodiversity (NBS } \\
2002 \text { ) }\end{array}$ & $\begin{array}{l}\text { Establish and } \\
\text { promote } \\
\text { appropriate } \\
\text { education and } \\
\text { awareness } \\
\text { programs to } \\
\text { facilitate } \\
\text { proper } \\
\text { community } \\
\text { participation in } \\
\text { the } \\
\text { conservation } \\
\text { of biodiversity } \\
\text { (Tanzania } \\
\text { NBSAP 2001) }\end{array}$ & $\begin{array}{l}\text { Individuals, } \\
\text { groups and } \\
\text { companies in the } \\
\text { host communities } \\
\text { are duly rewarded } \\
\text { during the eve of } \\
\text { the traditional } \\
\text { festival } \\
\text { observance }\end{array}$ & $\begin{array}{l}\text { Environmental } \\
\text { Protection Agency } \\
\text { Water Commission } \\
\text { Water and Sanitation } \\
\text { Agency } \\
\text { Ghana Tourism } \\
\text { Authority } \\
\text { Sponsors of the } \\
\text { traditional festivals } \\
\text { Export Development } \\
\text { and Agric Investment } \\
\text { Fund }\end{array}$ & $\begin{array}{l}\text { Host } \\
\text { communities of } \\
\text { traditional } \\
\text { festivals and } \\
\text { their } \\
\text { surrounding } \\
\text { communities }\end{array}$ & Annually \\
\hline
\end{tabular}




\begin{tabular}{|c|c|c|c|c|c|c|c|}
\hline Strategy (What) & $\begin{array}{l}\text { Target } \\
\text { (How) }\end{array}$ & $\begin{array}{l}\text { The complemented } \\
\text { Scientific } \\
\text { Conservation } \\
\text { Strategies }\end{array}$ & $\begin{array}{l}\text { Affiliated } \\
\text { International } \\
\text { Convention / } \\
\text { National } \\
\text { Legal } \\
\text { instrument / } \\
\text { Lessons from } \\
\text { Other } \\
\text { Countries } \\
\end{array}$ & $\begin{array}{l}\text { Description of } \\
\text { Indicator }\end{array}$ & $\begin{array}{l}\text { Implementation } \\
\text { Agencies/Actors } \\
\text { (Who) }\end{array}$ & $\begin{array}{l}\text { Jurisdiction for } \\
\text { Implementatio } \\
\mathbf{n} \\
\text { (Where) }\end{array}$ & $\begin{array}{l}\text { Frequency } \\
\text { (When) }\end{array}$ \\
\hline \multicolumn{8}{|c|}{$\begin{array}{l}\text { Action Plan 6: Ensuring the provision of the needed logistics and funding to support all traditional festivals in Ghana, especially, those that are linked to Protected Areas } \\
\text { with the aim of maintaining the resilience of their ecosystems }\end{array}$} \\
\hline $\begin{array}{l}\text { Mobilization of } \\
\text { funding and } \\
\text { logistics to } \\
\text { support traditional } \\
\text { festival } \\
\text { observations in } \\
\text { Ghana to enhance } \\
\text { the resilience of } \\
\text { Protected Areas } \\
\text { and their } \\
\text { ecosystems }\end{array}$ & $\begin{array}{l}\text { Provide the needed } \\
\text { support and funding } \\
\text { to festival organizers } \\
\text { to assist them } \\
\text { smoothly organize } \\
\text { the event to keep in } \\
\text { perpetual existence } \\
\text { all Protected Areas } \\
\text { that are directly } \\
\text { linked to the festival }\end{array}$ & $\begin{array}{l}\text { Develop systems and } \\
\text { incentive packages to } \\
\text { support public, the } \\
\text { private sector and } \\
\text { community investment } \\
\text { in reforestation and } \\
\text { forest plantation } \\
\text { development (Ghana } \\
\text { FWP 2012) } \\
\text { Secure sustainable } \\
\text { funding for the forestry } \\
\text { and wildlife sector } \\
\text { (Ghana FWP 2012) }\end{array}$ & $\begin{array}{l}\text { Restoring, and } \\
\text { safeguarding } \\
\text { ecosystems } \\
\text { that provide } \\
\text { essential } \\
\text { services, } \\
\text { including } \\
\text { ecological } \\
\text { services (CBD } \\
\text { Aichi Target } \\
\text { 14) }\end{array}$ & $\begin{array}{l}\text { Required funding } \\
\text { and logistics to } \\
\text { support traditional } \\
\text { festivals } \\
\text { observations in } \\
\text { Ghana are } \\
\text { generated }\end{array}$ & $\begin{array}{l}\text { Forestry } \\
\text { Commission } \\
\text { Traditional } \\
\text { Authorities } \\
\text { Festival } \\
\text { Organizing } \\
\text { Committees } \\
\text { Non-Government } \\
\text { al Organizations } \\
\text { for Conservation } \\
\text { (Conservation } \\
\text { International, } \\
\text { Friends of Rivers } \\
\text { and Water } \\
\text { Bodies) } \\
\text { Department of } \\
\text { Parks } \\
\text { Environmental } \\
\text { Protection } \\
\text { Agency }\end{array}$ & $\begin{array}{l}\text { Host } \\
\text { communities of } \\
\text { traditional } \\
\text { festivals and } \\
\text { their } \\
\text { surrounding } \\
\text { communities }\end{array}$ & Annually \\
\hline \multicolumn{8}{|c|}{$\begin{array}{l}\text { Action Plan 7: Promoting of biodiversity conservation ethics in Ghanaian citizens through the innovative utilization of cosmological belief systems for biodiversity } \\
\text { conservation education and awareness campaigns }\end{array}$} \\
\hline $\begin{array}{l}\text { Promotion of the } \\
\text { Ghanaian } \\
\text { cosmological } \\
\text { belief systems for } \\
\text { biodiversity } \\
\text { conservation } \\
\text { through the } \\
\text { development of } \\
\text { ethically } \\
\text { acceptable moral } \\
\text { behaviours in } \\
\text { Ghanaian citizens }\end{array}$ & $\begin{array}{l}\text { Capitalize on the } \\
\text { belief in God, } \\
\text { ancestors, spirits, } \\
\text { animism, sorcery and } \\
\text { witchcraft in } \\
\text { promoting ethically } \\
\text { acceptable } \\
\text { behaviours for } \\
\text { biodiversity } \\
\text { conservation }\end{array}$ & $\begin{array}{l}\text { Recognize the rights } \\
\text { of local people and } \\
\text { their customs and } \\
\text { belief systems that } \\
\text { lead to the } \\
\text { management of } \\
\text { biodiversity in sacred } \\
\text { sites (Ghana FWP } \\
\text { 2012) }\end{array}$ & $\begin{array}{l}\text { Preserve and } \\
\text { strengthen } \\
\text { religious, } \\
\text { ritualistic, } \\
\text { ethical and } \\
\text { cultural } \\
\text { methods of } \\
\text { conservation } \\
\text { (India NBSAP } \\
\text { 2008) }\end{array}$ & $\begin{array}{l}\text { Ghanaian } \\
\text { Cosmological } \\
\text { belief systems } \\
\text { have been used in } \\
\text { promoting } \\
\text { ethically } \\
\text { acceptable } \\
\text { behaviours for } \\
\text { biodiversity } \\
\text { conservation in } \\
\text { citizens }\end{array}$ & $\begin{array}{l}\text { Religious groups } \\
\text { (Christianity, } \\
\text { Islamic, African } \\
\text { Traditional } \\
\text { Religion) } \\
\text { Traditional } \\
\text { Authorities } \\
\text { Forestry } \\
\text { Commission } \\
\text { Wildlife Division } \\
\text { Environmental } \\
\text { Protection Agency }\end{array}$ & $\begin{array}{l}\text { Ghanaian } \\
\text { communities }\end{array}$ & Periodically \\
\hline \multicolumn{8}{|c|}{$\begin{array}{l}\text { Action Plan 8: Affiliating particular spots and biodiversity species in Ghanaian societies where species richness is threatened and/or is close to extinction to known deities, } \\
\text { ancestors and personalities in the communities }\end{array}$} \\
\hline $\begin{array}{l}\text { Protect threatened } \\
\text { biodiversity } \\
\text { species in } \\
\text { particular spots } \\
\text { through } \\
\text { dedication or } \\
\text { defying them to } \\
\text { known } \\
\text { spirits/deities/ } \\
\text { ancestors in } \\
\text { Ghanaian } \\
\text { communities }\end{array}$ & $\begin{array}{l}\text { Dedicate particular } \\
\text { forest tracts, flora or } \\
\text { fauna species to } \\
\text { known } \\
\text { spirits/deities/ancesto } \\
\text { rs revered by the } \\
\text { people in the various } \\
\text { parts of Ghana }\end{array}$ & $\begin{array}{l}\text { Managing and enhancing the } \\
\text { ecological stability of } \\
\text { Ghana's forests and the } \\
\text { conservation of biological } \\
\text { diversity through biological } \\
\text { inventories, biological and } \\
\text { ecological indicators and } \\
\text { creation of wildlife corridors } \\
\text { (Ghana FWP 2012) } \\
\text { Maintaining the secrecy of } \\
\text { the spirituality of sacred } \\
\text { natural sites for biodiversity } \\
\text { conservation (Ghana FWP } \\
\text { 2012) }\end{array}$ & $\begin{array}{l}\text { Indigenous } \\
\text { people have the } \\
\text { right to manifest, } \\
\text { practice, develop } \\
\text { and teach their } \\
\text { spiritual and } \\
\text { religious, customs } \\
\text { and ceremonies } \\
\text { regarding sacred } \\
\text { sites } \\
\text { (UNDRIP 2006, } \\
\text { Article 12) }\end{array}$ & $\begin{array}{l}\text { Threatened } \\
\text { biodiversity } \\
\text { species and spots } \\
\text { are dedicated or } \\
\text { deified after } \\
\text { known } \\
\text { ancestors/spirits/ } \\
\text { deities in the } \\
\text { Ghanaian } \\
\text { communities }\end{array}$ & $\begin{array}{l}\text { Traditional } \\
\text { Authorities } \\
\text { Forestry } \\
\text { Commission }\end{array}$ & $\begin{array}{l}\text { Ghanaian } \\
\text { communities } \\
\text { with endemic } \\
\text { and/or } \\
\text { threatened } \\
\text { biodiversity } \\
\text { species and } \\
\text { spots }\end{array}$ & Periodically \\
\hline
\end{tabular}




\begin{tabular}{|c|c|c|c|c|c|c|c|}
\hline Strategy (What) & $\begin{array}{l}\text { Target } \\
\text { (How) }\end{array}$ & $\begin{array}{l}\text { The complemented } \\
\text { Scientific } \\
\text { Conservation } \\
\text { Strategies }\end{array}$ & $\begin{array}{l}\text { Affiliated } \\
\text { International } \\
\text { Convention / } \\
\text { National } \\
\text { Legal } \\
\text { instrument / } \\
\text { Lessons from } \\
\text { Other } \\
\text { Countries }\end{array}$ & $\begin{array}{l}\text { Description of } \\
\text { Indicator }\end{array}$ & $\begin{array}{l}\text { Implementation } \\
\text { Agencies/Actors } \\
\text { (Who) }\end{array}$ & $\begin{array}{l}\text { Jurisdiction for } \\
\text { Implementatio } \\
\mathbf{n} \\
\text { (Where) }\end{array}$ & $\begin{array}{l}\text { Frequency } \\
\text { (When) }\end{array}$ \\
\hline \multicolumn{8}{|c|}{ Action Plan 9: Innovatively using community meeting days in promoting and developing the conservation ethics espoused in Proverbs for biodiversity conservation } \\
\hline $\begin{array}{l}\text { Utilize taboo days } \\
\text { and other public } \\
\text { holidays in } \\
\text { instructing society } \\
\text { members on the } \\
\text { sound } \\
\text { conservation } \\
\text { ethics in } \\
\text { Ghanaian } \\
\text { proverbs }\end{array}$ & $\begin{array}{l}\text { Educate society } \\
\text { members on the } \\
\text { philosophical imports } \\
\text { of Ghanaian proverbs } \\
\text { that advocate the } \\
\text { engagement in } \\
\text { healthy } \\
\text { environmental } \\
\text { practices that } \\
\text { promote biodiversity } \\
\text { conservation }\end{array}$ & $\begin{array}{l}\text { Promotion of public } \\
\text { awareness and } \\
\text { involvement of rural } \\
\text { people in forest and } \\
\text { wildlife conservation } \\
\text { (Ghana 1994 FWP) }\end{array}$ & $\begin{array}{l}\text { Establish and } \\
\text { promote } \\
\text { appropriate } \\
\text { education and } \\
\text { awareness } \\
\text { programmes to } \\
\text { facilitate } \\
\text { proper } \\
\text { community } \\
\text { participation in } \\
\text { the } \\
\text { conservation } \\
\text { of biodiversity } \\
\text { (Tanzania } \\
\text { NBSAP 2001) }\end{array}$ & $\begin{array}{l}\text { Society members } \\
\text { are well educated } \\
\text { on the } \\
\text { philosophical } \\
\text { imports of } \\
\text { Ghanaian } \\
\text { proverbs for the } \\
\text { development of } \\
\text { biodiversity } \\
\text { conservation } \\
\text { ethics }\end{array}$ & $\begin{array}{l}\text { Traditional } \\
\text { Authorities } \\
\text { Forestry } \\
\text { Commission } \\
\text { Wildlife Division } \\
\text { Department of } \\
\text { Parks } \\
\text { Cultural Experts } \\
\text { Elders in the } \\
\text { society }\end{array}$ & $\begin{array}{l}\text { Ghanaian } \\
\text { communities }\end{array}$ & Periodically \\
\hline \multicolumn{8}{|c|}{ Action Plan 10: Incorporating the conservation ethos in Ghanaian proverbs into the biodiversity conservation education at the various levels of education in Ghana } \\
\hline \multirow[t]{2}{*}{$\begin{array}{l}\text { Introduce the use } \\
\text { of Ghanaian } \\
\text { proverbs into } \\
\text { biodiversity } \\
\text { conservation } \\
\text { education at all } \\
\text { levels of } \\
\text { education }\end{array}$} & $\begin{array}{l}\text { Introduce new subjects or } \\
\text { courses on traditional } \\
\text { biodiversity conservation } \\
\text { education using Ghanaian } \\
\text { proverbs and/or integrate } \\
\text { into existing } \\
\text { environmental education } \\
\text { courses and subjects in } \\
\text { schools }\end{array}$ & \multirow[t]{2}{*}{$\begin{array}{l}\text { Encouraging } \\
\text { institutions of higher } \\
\text { learning and corporate } \\
\text { bodies to integrate } \\
\text { indigenous knowledge } \\
\text { and scientific } \\
\text { knowledge into forest } \\
\text { and wildlife } \\
\text { management (Ghana } \\
\text { WFP 2012) }\end{array}$} & $\begin{array}{l}\text { Establish and } \\
\text { promote } \\
\text { appropriate } \\
\text { education and } \\
\text { awareness } \\
\text { programmes to } \\
\text { facilitate } \\
\text { proper } \\
\text { community } \\
\text { participation in } \\
\text { the } \\
\text { conservation } \\
\text { of biodiversity } \\
\text { (Tanzania } \\
\text { NBSAP 2001) }\end{array}$ & $\begin{array}{l}\text { The study of } \\
\text { biodiversity-relate } \\
\text { d proverbs } \\
\text { streamlined into } \\
\text { educational } \\
\text { curriculum at all } \\
\text { education levels } \\
\text { in Ghana } \\
\text { New subjects on } \\
\text { traditional biodiversity } \\
\text { conservation } \\
\text { education using } \\
\text { Ghanaian proverbs } \\
\text { introduced and } \\
\text { integrated into } \\
\text { environmental } \\
\text { education courses i }\end{array}$ & $\begin{array}{l}\text { Ghana Education } \\
\text { Service } \\
\text { National Council } \\
\text { for Curriculum } \\
\text { and Assessment } \\
\text { Department of } \\
\text { Cultural studies in } \\
\text { universities in } \\
\text { Ghana } \\
\text { (KNUST, UCC, } \\
\text { UG etc.) } \\
\text { Cultural Experts }\end{array}$ & $\begin{array}{l}\text { All educational } \\
\text { institutions at all } \\
\text { levels of the } \\
\text { academic ladder } \\
\text { in Ghana: } \\
\text { Elementary } \\
\text { schools } \\
\text { Junior High } \\
\text { Schools } \\
\text { Senior High } \\
\text { Schools } \\
\text { Tertiary } \\
\text { institutions }\end{array}$ & Regularly \\
\hline & $\begin{array}{l}\text { Promote collaboration } \\
\text { between the National } \\
\text { Commission on Culture, } \\
\text { Colleges in charge of } \\
\text { Cultural Education and } \\
\text { the Ministry of Education } \\
\text { to organize workshops } \\
\text { and seminars on the } \\
\text { traditional epistemologies } \\
\text { in Proverbs for } \\
\text { biodiversity conservation } \\
\text { education in all } \\
\text { educational institutions in } \\
\text { Ghana }\end{array}$ & & $\begin{array}{l}\text { Incorporate } \\
\text { traditional } \\
\text { knowledge into } \\
\text { formal education } \\
\text { with the Ministry } \\
\text { of Culture and the } \\
\text { University of } \\
\text { Brasilia } \\
\text { collaborating to } \\
\text { promote the } \\
\text { participation of } \\
\text { instructors from } \\
\text { traditional cultures } \\
\text { on workshops in } \\
\text { biodiversity } \\
\text { conservation } \\
\text { (Brazil NBSAP } \\
\text { 2010) }\end{array}$ & $\begin{array}{l}\text { Workshops and } \\
\text { seminars on the } \\
\text { traditional } \\
\text { epistemologies in } \\
\text { Ghanaian proverbs } \\
\text { for biodiversity } \\
\text { conservation } \\
\text { education through } \\
\text { an effective } \\
\text { collaboration } \\
\text { between } \\
\text { institutions for } \\
\text { cultural education } \\
\text { and the Ministry of } \\
\text { Education }\end{array}$ & $\begin{array}{l}\text { National } \\
\text { Commission on } \\
\text { Culture } \\
\text { Ministry of } \\
\text { Education } \\
\text { Institutions of } \\
\text { Higher Learning } \\
\text { on Cultural } \\
\text { Education } \\
\text { Cultural Experts } \\
\text { Forestry } \\
\text { Commission } \\
\text { Wildlife Division }\end{array}$ & $\begin{array}{l}\text { All educational } \\
\text { institutions at all } \\
\text { levels of the } \\
\text { academic ladder } \\
\text { in Ghana: } \\
\text { Elementary } \\
\text { schools } \\
\text { Junior High } \\
\text { Schools } \\
\text { Senior High } \\
\text { Schools } \\
\text { Tertiary } \\
\text { institutions }\end{array}$ & Regularly \\
\hline
\end{tabular}




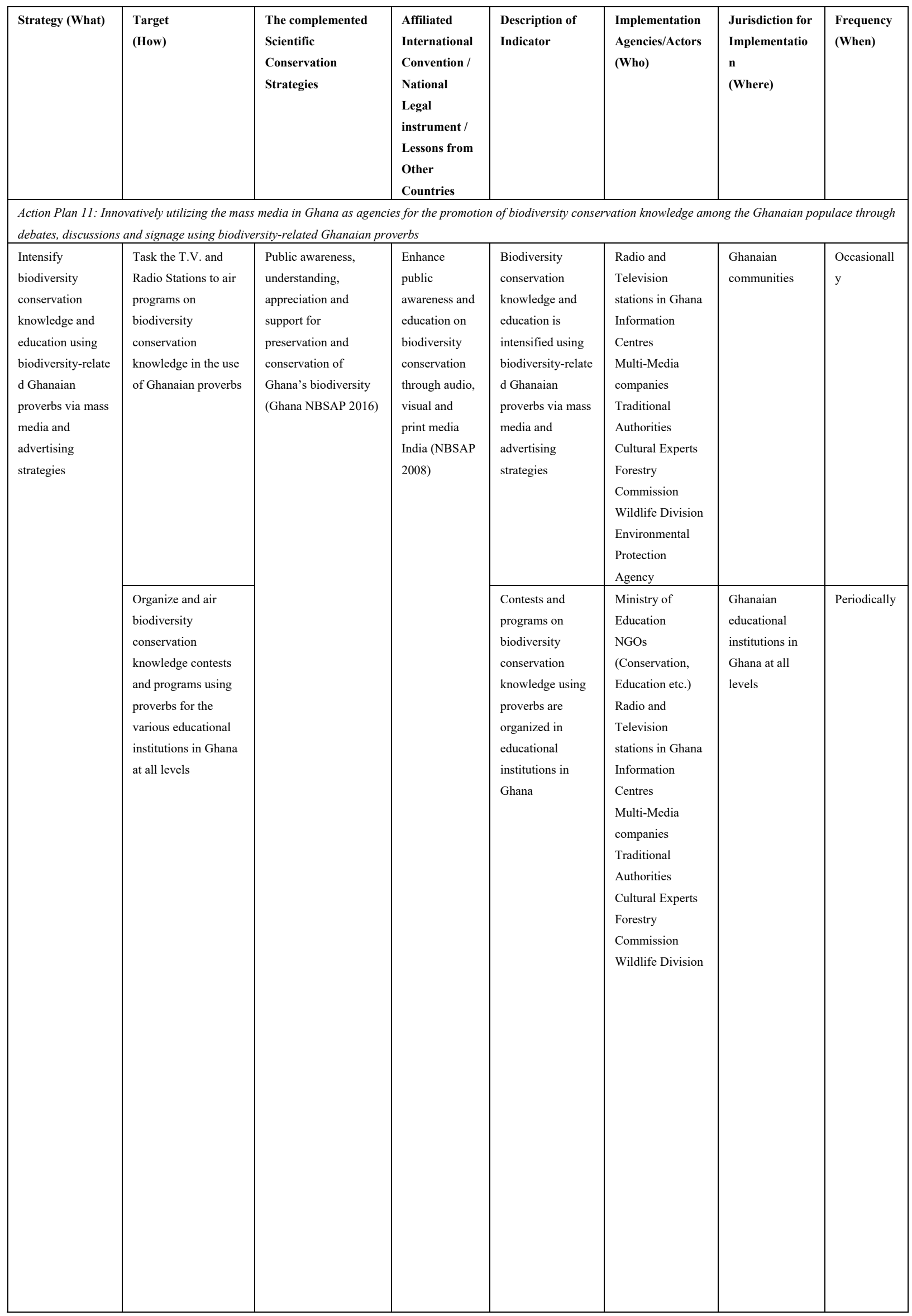




\begin{tabular}{|c|c|c|c|c|c|c|c|}
\hline Strategy (What) & $\begin{array}{l}\text { Target } \\
\text { (How) }\end{array}$ & $\begin{array}{l}\text { The complemented } \\
\text { Scientific } \\
\text { Conservation } \\
\text { Strategies }\end{array}$ & $\begin{array}{l}\text { Affiliated } \\
\text { International } \\
\text { Convention / } \\
\text { National } \\
\text { Legal } \\
\text { instrument / } \\
\text { Lessons from } \\
\text { Other } \\
\text { Countries }\end{array}$ & $\begin{array}{l}\text { Description of } \\
\text { Indicator }\end{array}$ & $\begin{array}{l}\text { Implementation } \\
\text { Agencies/Actors } \\
\text { (Who) }\end{array}$ & $\begin{array}{l}\text { Jurisdiction for } \\
\text { Implementatio } \\
\mathbf{n} \\
\text { (Where) }\end{array}$ & $\begin{array}{l}\text { Frequency } \\
\text { (When) }\end{array}$ \\
\hline & $\begin{array}{l}\text { Use social media } \\
\text { platforms such as the } \\
\text { internet websites of } \\
\text { conservation agencies } \\
\text { to showcase proverbs } \\
\text { for biodiversity } \\
\text { conservation } \\
\text { education }\end{array}$ & $\begin{array}{l}\text { Educate the public on } \\
\text { traditional knowledge } \\
\text { issues on biodiversity } \\
\text { (NBSAP 2016) }\end{array}$ & $\begin{array}{l}\text { The } \\
\text { government } \\
\text { will utilize } \\
\text { internet } \\
\text { websites to } \\
\text { publicize } \\
\text { biodiversity } \\
\text { initiatives to } \\
\text { deepen } \\
\text { citizens' } \\
\text { understanding } \\
\text { of the natural } \\
\text { environment }\end{array}$ & $\begin{array}{l}\text { The websites of } \\
\text { conservation } \\
\text { bodies and other } \\
\text { media outlets to } \\
\text { be used as } \\
\text { platforms in } \\
\text { disseminating } \\
\text { biodiversity }\end{array}$ & $\begin{array}{l}\text { Social Media } \\
\text { Networks } \\
\text { NGOs } \\
\text { Environmental } \\
\text { Protection } \\
\text { Agency }\end{array}$ & $\begin{array}{l}\text { All Social } \\
\text { Media Outlets in } \\
\text { Ghana }\end{array}$ & Regularly \\
\hline & $\begin{array}{l}\text { Embark on the } \\
\text { designing and use of } \\
\text { signage on the major } \\
\text { streets and vantage } \\
\text { points in the } \\
\text { Ghanaian society for } \\
\text { publicizing } \\
\text { biodiversity-related } \\
\text { proverbs for } \\
\text { biodiversity } \\
\text { conservation } \\
\text { education and } \\
\text { sensitization }\end{array}$ & $\begin{array}{l}\text { Prepare and publish } \\
\text { information on } \\
\text { biodiversity } \\
\text { conservation (NBSAP } \\
2016)\end{array}$ & $\begin{array}{l}\text { Enhance } \\
\text { public } \\
\text { awareness and } \\
\text { education on } \\
\text { biodiversity } \\
\text { conservation } \\
\text { through audio, } \\
\text { visual and } \\
\text { print media } \\
\text { India } \\
\text { (NBSAP 2008) }\end{array}$ & $\begin{array}{l}\text { Biodiversity } \\
\text { conservation } \\
\text { education, } \\
\text { awareness and } \\
\text { sensitization via } \\
\text { Ghanaian } \\
\text { proverbs to be } \\
\text { carried out using } \\
\text { signage placed at } \\
\text { vantage points in } \\
\text { the Ghanaian } \\
\text { society }\end{array}$ & $\begin{array}{l}\text { Communication } \\
\text { Media companies in } \\
\text { Ghana } \\
\text { Municipal and } \\
\text { Metropolitan } \\
\text { Assemblies in Ghana } \\
\text { Environmental } \\
\text { Protection Agency } \\
\text { Forestry Commission } \\
\text { Wildlife Division } \\
\text { NGOs (Conservation } \\
\text { and Environmental } \\
\text { Education) } \\
\text { Department of Parks }\end{array}$ & $\begin{array}{l}\text { Vantage spots in } \\
\text { all the Ghanaian } \\
\text { communities }\end{array}$ & Periodically \\
\hline \multicolumn{8}{|c|}{ Action Plan 12: Actively involving the local people who are the owners of biodiversity in the planning, development and management of biodiversity in their jurisdiction } \\
\hline \multirow[t]{2}{*}{$\begin{array}{l}\text { Actively involve } \\
\text { local people in the } \\
\text { decision-making } \\
\text { processes in } \\
\text { biodiversity } \\
\text { management }\end{array}$} & $\begin{array}{l}\text { Use the media outlet } \\
\text { to sensitize the } \\
\text { general public on the } \\
\text { rights of local people } \\
\text { in biodiversity } \\
\text { management }\end{array}$ & $\begin{array}{l}\text { Enhance active } \\
\text { participation of } \\
\text { communities and } \\
\text { landowners in } \\
\text { resource management } \\
\text { and addressing issues } \\
\text { on tree tenure and } \\
\text { benefit sharing (Ghana } \\
\text { FWP 2012) }\end{array}$ & $\begin{array}{l}\text { Guarantee } \\
\text { through the } \\
\text { media, the } \\
\text { recognition of } \\
\text { the rights of } \\
\text { communities } \\
\text { in biodiversity } \\
\text { management } \\
\text { (Angola } \\
\text { NBSAP } \\
\text { 2007-2012) }\end{array}$ & $\begin{array}{l}\text { Local people are } \\
\text { involved in all the } \\
\text { decision making } \\
\text { processes in } \\
\text { biodiversity } \\
\text { management }\end{array}$ & \multirow{2}{*}{$\begin{array}{l}\text { Ministry of Local } \\
\text { Government and } \\
\text { Rural } \\
\text { Development } \\
\text { Forestry } \\
\text { Commission } \\
\text { Wildlife Division } \\
\text { National } \\
\text { Biodiversity } \\
\text { Committee } \\
\text { National House of } \\
\text { Chiefs } \\
\text { Media Outlets } \\
\text { Traditional } \\
\text { Authorities } \\
\text { Non-Government } \\
\text { al Organizations } \\
\text { in charge of the } \\
\text { Rights of Local } \\
\text { People }\end{array}$} & \multirow[t]{2}{*}{$\begin{array}{l}\text { All biodiversity } \\
\text { management } \\
\text { meetings in the } \\
\text { country } \\
\text { (Planning, } \\
\text { Decision-makin } \\
\mathrm{g}, \text { Consultations } \\
\text { etc) }\end{array}$} & Regularly \\
\hline & $\begin{array}{l}\text { Adopt community } \\
\text { participation } \\
\text { approaches typical of } \\
\text { local communities to } \\
\text { boost the } \\
\text { involvement of } \\
\text { community members } \\
\text { in biodiversity } \\
\text { management schemes }\end{array}$ & $\begin{array}{l}\text { Enhance active } \\
\text { participation of } \\
\text { communities and } \\
\text { landowners in } \\
\text { resource management } \\
\text { (Ghana WFP 2012) }\end{array}$ & $\begin{array}{l}\text { Adopt } \\
\text { community } \\
\text { participation } \\
\text { approaches in } \\
\text { the } \\
\text { development } \\
\text { and } \\
\text { management } \\
\text { of biological } \\
\text { diversity } \\
\text { (Tanzania } \\
\text { NBSAP 2001) }\end{array}$ & $\begin{array}{l}\text { Local community } \\
\text { participation is } \\
\text { boosted through } \\
\text { an adaptation of } \\
\text { community } \\
\text { participation } \\
\text { approaches. }\end{array}$ & & & Periodically \\
\hline
\end{tabular}




\begin{tabular}{|c|c|c|c|c|c|c|c|}
\hline Strategy (What) & $\begin{array}{l}\text { Target } \\
\text { (How) }\end{array}$ & $\begin{array}{l}\text { The complemented } \\
\text { Scientific } \\
\text { Conservation } \\
\text { Strategies }\end{array}$ & $\begin{array}{l}\text { Affiliated } \\
\text { International } \\
\text { Convention / } \\
\text { National } \\
\text { Legal } \\
\text { instrument / } \\
\text { Lessons from } \\
\text { Other } \\
\text { Countries } \\
\end{array}$ & $\begin{array}{l}\text { Description of } \\
\text { Indicator }\end{array}$ & $\begin{array}{l}\text { Implementation } \\
\text { Agencies/Actors } \\
\text { (Who) }\end{array}$ & $\begin{array}{l}\text { Jurisdiction for } \\
\text { Implementatio } \\
\text { n } \\
\text { (Where) }\end{array}$ & $\begin{array}{l}\text { Frequency } \\
\text { (When) }\end{array}$ \\
\hline \multicolumn{8}{|c|}{ Action Plan 13: Ensuring the fair and equitable distribution of biological diversity resources in favour of the owners in local communities } \\
\hline \multirow[t]{2}{*}{$\begin{array}{l}\text { Educate the } \\
\text { traditional } \\
\text { authorities in } \\
\text { local communities } \\
\text { on their benefits } \\
\text { and the mode of } \\
\text { equitable sharing } \\
\text { of the biodiversity }\end{array}$} & $\begin{array}{l}\text { Organize workshops } \\
\text { to educate traditional } \\
\text { authorities on the } \\
\text { benefits and mode of } \\
\text { equitable sharing of } \\
\text { their biodiversity } \\
\text { resources }\end{array}$ & $\begin{array}{l}\text { The community-based } \\
\text { incentive system for } \\
\text { ecosystem services } \\
\text { (Ghana } \\
\text { NBSAP 2016) }\end{array}$ & $\begin{array}{l}\text { Provide } \\
\text { training to } \\
\text { traditional } \\
\text { authorities on } \\
\text { their rights to } \\
\text { the } \\
\text { biodiversity } \\
\text { resources } \\
\text { (Angola } \\
\text { NBSAP } \\
\text { 2007-2012) } \\
\text { Devise } \\
\text { mechanisms } \\
\text { for providing } \\
\text { benefits from } \\
\text { biodiversity to } \\
\text { local } \\
\text { communities } \\
\text { (India NBSAP } \\
\text { 2008) }\end{array}$ & $\begin{array}{l}\text { The owners of } \\
\text { biodiversity in } \\
\text { local communities } \\
\text { are abreast with } \\
\text { the mode of } \\
\text { equitable sharing } \\
\text { of the benefits of } \\
\text { biodiversity } \\
\text { proceeds }\end{array}$ & \multirow[t]{2}{*}{$\begin{array}{l}\text { Ministry of } \\
\text { Environment, } \\
\text { Science, } \\
\text { Technology and } \\
\text { Innovation } \\
\text { Forestry } \\
\text { Commission } \\
\text { Wildlife Division } \\
\text { Department of } \\
\text { Parks } \\
\text { Ministry of Local } \\
\text { Government and } \\
\text { Rural } \\
\text { Development }\end{array}$} & $\begin{array}{l}\text { Ghanaian local } \\
\text { communities } \\
\text { with Pas }\end{array}$ & Periodically \\
\hline & $\begin{array}{l}\text { Employ local } \\
\text { residents living in the } \\
\text { forest fringe } \\
\text { communities around } \\
\text { Protected Areas in } \\
\text { conservation projects }\end{array}$ & $\begin{array}{l}\text { Increase rural } \\
\text { employment through } \\
\text { the local management } \\
\text { of off-reserve forests } \\
\text { through mechanisms } \\
\text { such as dedicated } \\
\text { forests or Community } \\
\text { Resource } \\
\text { Management Areas } \\
\text { (Ghana WFP 2012) }\end{array}$ & $\begin{array}{l}\text { The } \\
\text { government } \\
\text { will work at } \\
\text { recruiting } \\
\text { human } \\
\text { resources } \\
\text { especially rural } \\
\text { folks who will } \\
\text { engage in } \\
\text { conservation } \\
\text { activities } \\
\text { (Japan NBSAP } \\
\text { 2020) }\end{array}$ & $\begin{array}{l}\text { The employment } \\
\text { of rural people } \\
\text { living in the forest } \\
\text { fringe } \\
\text { communities is } \\
\text { increased. }\end{array}$ & & $\begin{array}{l}\text { Ghanaian local } \\
\text { communities } \\
\text { with PAs }\end{array}$ & $\begin{array}{l}\text { As and } \\
\text { when the } \\
\text { need arises }\end{array}$ \\
\hline \multicolumn{8}{|c|}{ Action Plan 14: Facilitating and empowering the capacity of local government (Traditional Authorities) in enforcing biodiversity legislation in their local communities } \\
\hline $\begin{array}{l}\text { Equip the } \\
\text { traditional } \\
\text { authorities in the } \\
\text { local communities } \\
\text { with the legal } \\
\text { rights in enforcing } \\
\text { biodiversity } \\
\text { legislation in their } \\
\text { local communities }\end{array}$ & $\begin{array}{l}\text { Empower traditional } \\
\text { authorities in the } \\
\text { local communities } \\
\text { with the legal right to } \\
\text { inspect, prosecute } \\
\text { and punish defaulters } \\
\text { of unfriendly } \\
\text { biodiversity activities } \\
\text { in their jurisdiction }\end{array}$ & $\begin{array}{l}\text { The } \\
\text { community-governme } \\
\text { nt collaborative } \\
\text { management approach } \\
\text { (Ghana FWP 2012) } \\
\text { Promote the } \\
\text { traditional autonomy } \\
\text { for the management of } \\
\text { sacred and community } \\
\text { dedicated forests } \\
\text { (Ghana FWP 2012) }\end{array}$ & $\begin{array}{l}\text { Facilitate the } \\
\text { enhancement } \\
\text { of local } \\
\text { government } \\
\text { capacity to } \\
\text { enforce } \\
\text { (inspectorate, } \\
\text { prosecution } \\
\text { and } \\
\text { punishment of } \\
\text { defaulters) } \\
\text { environmental } \\
\text { legislation } \\
\text { (Tanzania } \\
\text { NBSAP 2001) }\end{array}$ & $\begin{array}{l}\text { Traditional } \\
\text { authorities in } \\
\text { local communities } \\
\text { would be } \\
\text { empowered to } \\
\text { inspect, prosecute } \\
\text { and punish } \\
\text { defaulters of } \\
\text { unfriendly } \\
\text { biodiversity } \\
\text { activities in their } \\
\text { jurisdiction }\end{array}$ & $\begin{array}{l}\text { Traditional } \\
\text { Authorities } \\
\text { Environmental } \\
\text { Protection } \\
\text { Agency } \\
\text { Forestry } \\
\text { Commission } \\
\text { Wildlife Division } \\
\text { Department of } \\
\text { Parks } \\
\text { Ministry of Local } \\
\text { Government and } \\
\text { Rural } \\
\text { Development }\end{array}$ & $\begin{array}{l}\text { Ghanaian local } \\
\text { communities }\end{array}$ & Regularly \\
\hline
\end{tabular}




\begin{tabular}{|c|c|c|c|c|c|c|c|}
\hline Strategy (What) & $\begin{array}{l}\text { Target } \\
\text { (How) }\end{array}$ & $\begin{array}{l}\text { The complemented } \\
\text { Scientific } \\
\text { Conservation } \\
\text { Strategies }\end{array}$ & $\begin{array}{l}\text { Affiliated } \\
\text { International } \\
\text { Convention / } \\
\text { National } \\
\text { Legal } \\
\text { instrument / } \\
\text { Lessons from } \\
\text { Other } \\
\text { Countries }\end{array}$ & $\begin{array}{l}\text { Description of } \\
\text { Indicator }\end{array}$ & $\begin{array}{l}\text { Implementation } \\
\text { Agencies/Actors } \\
\text { (Who) }\end{array}$ & $\begin{array}{l}\text { Jurisdiction for } \\
\text { Implementatio } \\
\mathbf{n} \\
\text { (Where) }\end{array}$ & $\begin{array}{l}\text { Frequency } \\
\text { (When) }\end{array}$ \\
\hline \multicolumn{8}{|c|}{ Action Plan 15: Studying traditional conservation practices to equip conservationists to know how to implement them in the local communities } \\
\hline $\begin{array}{l}\text { Educate the } \\
\text { conservationists } \\
\text { on the traditional } \\
\text { conservation } \\
\text { practices and their } \\
\text { great potentials in } \\
\text { biodiversity } \\
\text { conservation }\end{array}$ & $\begin{array}{l}\text { Organise workshops, } \\
\text { seminars and a short } \\
\text { course on the } \\
\text { traditional knowledge } \\
\text { systems and their } \\
\text { relevance in } \\
\text { biodiversity } \\
\text { conservation }\end{array}$ & $\begin{array}{l}\text { Incorporate the useful } \\
\text { wealth of traditional } \\
\text { conservation } \\
\text { knowledge into } \\
\text { modern technologies } \\
\text { (NBS 2002) } \\
\text { Educate the public on } \\
\text { traditional knowledge } \\
\text { issues on biodiversity } \\
\text { (NBSAP 2016) }\end{array}$ & $\begin{array}{l}\text { Provide } \\
\text { training to } \\
\text { forest rangers, } \\
\text { forest guards } \\
\text { etc. on the } \\
\text { potentials of } \\
\text { traditional } \\
\text { knowledge } \\
\text { systems } \\
\text { (Tanzania } \\
\text { NBSAP 2001) }\end{array}$ & $\begin{array}{l}\text { Conservationists } \\
\text { are to be well } \\
\text { educated on } \\
\text { traditional } \\
\text { conservation } \\
\text { practices and their } \\
\text { great potentials in } \\
\text { biodiversity } \\
\text { conservation }\end{array}$ & $\begin{array}{l}\text { Culturists in } \\
\text { Universities and } \\
\text { other institutions } \\
\text { of Higher } \\
\text { Learning on } \\
\text { Cultural Studies } \\
\text { Traditional } \\
\text { Authorities } \\
\text { Cultural Experts } \\
\text { in local } \\
\text { communities in } \\
\text { Ghana } \\
\text { Ministry of } \\
\text { Education } \\
\text { National } \\
\text { Commission on } \\
\text { Culture } \\
\text { National House of } \\
\text { Chiefs }\end{array}$ & $\begin{array}{l}\text { Conservationists } \\
\text { working in all } \\
\text { the conservation } \\
\text { agencies in } \\
\text { Ghana }\end{array}$ & Periodically \\
\hline \multicolumn{8}{|c|}{ Action Plan 16: Studying scientific conservation models to equip traditional authorities to know how to support their implementation processes in their communities } \\
\hline $\begin{array}{l}\text { Educate the } \\
\text { traditional } \\
\text { authorities on the } \\
\text { scientific } \\
\text { conservation } \\
\text { practices and their } \\
\text { great potentials in } \\
\text { biodiversity } \\
\text { conservation }\end{array}$ & $\begin{array}{l}\text { Organise workshops, } \\
\text { seminars and a short } \\
\text { course on the } \\
\text { scientific knowledge } \\
\text { practices and their } \\
\text { relevance in } \\
\text { biodiversity } \\
\text { conservation for } \\
\text { traditional authorities }\end{array}$ & $\begin{array}{l}\text { Empower traditional } \\
\text { authorities in the } \\
\text { management of } \\
\text { biodiversity (NBS } \\
2002 \text { ) }\end{array}$ & $\begin{array}{l}\text { Provide } \\
\text { training to } \\
\text { traditional } \\
\text { authorities on } \\
\text { scientific } \\
\text { methods of } \\
\text { biodiversity } \\
\text { management } \\
\text { (Tanzania } \\
\text { NBSAP 2001) }\end{array}$ & $\begin{array}{l}\text { Traditional } \\
\text { Authorities would } \\
\text { be educated on } \\
\text { the scientific } \\
\text { conservation } \\
\text { practices and their } \\
\text { great potentials in } \\
\text { biodiversity } \\
\text { conservation }\end{array}$ & $\begin{array}{l}\text { Conservationists } \\
\text { in Universities, } \\
\text { RMSC, FORIG } \\
\text { and other } \\
\text { institutions of } \\
\text { Higher Learning } \\
\text { on Cultural } \\
\text { Studies } \\
\text { Ministry of } \\
\text { Education } \\
\text { Forestry } \\
\text { Commission } \\
\text { Wildlife Division } \\
\text { Department of } \\
\text { Parks }\end{array}$ & $\begin{array}{l}\text { Traditional } \\
\text { Authorities in } \\
\text { local } \\
\text { communities in } \\
\text { Ghana }\end{array}$ & Periodically \\
\hline \multicolumn{8}{|c|}{ Action Plan 17: Strengthening the relationship between conservationists and traditional authorities in the Ghanaian communities } \\
\hline $\begin{array}{l}\text { Beef up the } \\
\text { relationship } \\
\text { between } \\
\text { conservationists } \\
\text { and traditional } \\
\text { authorities }\end{array}$ & $\begin{array}{l}\text { Organise forums for } \\
\text { conservationists and } \\
\text { traditional authorities } \\
\text { where there would be } \\
\text { a deliberation on the } \\
\text { application of both } \\
\text { scientific and } \\
\text { traditional knowledge } \\
\text { in biodiversity } \\
\text { Hold seminars on } \\
\text { how to improve the } \\
\text { interpersonal } \\
\text { relationships between } \\
\text { conservationists and } \\
\text { traditional authorities }\end{array}$ & $\begin{array}{l}\text { Integrate traditional } \\
\text { and scientific } \\
\text { knowledge to promote } \\
\text { sustainable } \\
\text { management of } \\
\text { biodiversity } \\
\text { (Ghana WFP 2012) }\end{array}$ & $\begin{array}{l}\text { Sustainability } \\
\text { of biodiversity } \\
\text { through the } \\
\text { application of } \\
\text { modern and } \\
\text { indigenous } \\
\text { technologies } \\
\text { (Kenya } \\
\text { NBSAP 2000) }\end{array}$ & $\begin{array}{l}\text { Forums are } \\
\text { organized to } \\
\text { deliberate on the } \\
\text { application of both } \\
\text { scientific and } \\
\text { traditional } \\
\text { knowledge in } \\
\text { biodiversity } \\
\text { conservation } \\
\text { Seminars held to } \\
\text { improve the } \\
\text { relationship betweem } \\
\text { conservationists and } \\
\text { traditional authorities }\end{array}$ & $\begin{array}{l}\text { Human Resource } \\
\text { Experts } \\
\text { Conservationists } \\
\text { Traditional } \\
\text { Authorities } \\
\text { Ministry of } \\
\text { Environment, } \\
\text { Science, } \\
\text { Technology and } \\
\text { Innovation } \\
\text { Forestry } \\
\text { Commission } \\
\text { Wildlife Division } \\
\text { Department of } \\
\text { Parks and Gardens }\end{array}$ & $\begin{array}{l}\text { Conservationists } \\
\text { working in } \\
\text { forest fringe } \\
\text { communities in } \\
\text { Ghana }\end{array}$ & Periodically \\
\hline
\end{tabular}




\section{Copyrights}

Copyright for this article is retained by the author(s), with first publication rights granted to the journal.

This is an open-access article distributed under the terms and conditions of the Creative Commons Attribution license (http://creativecommons.org/licenses/by/4.0/). 